\title{
Data report: quantitative powder X-ray diffraction analysis from the Canterbury Basin, Expedition 317
}

\author{
Tania Villaseñor ${ }^{2}$ and John M. Jaeger ${ }^{2}$
}

\section{Chapter contents}

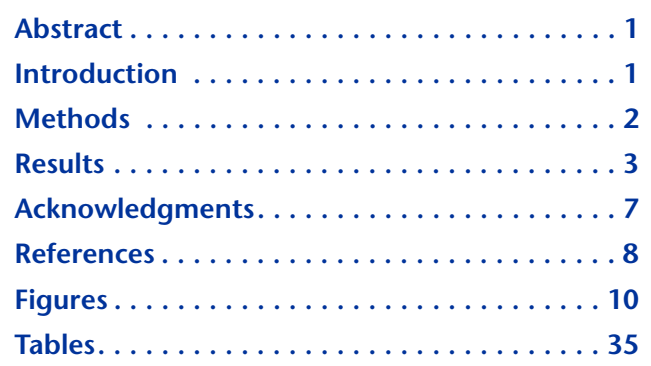

1Villaseñor, T., and Jaeger, J.M., 2013. Data report: quantitative powder $\mathrm{X}$-ray diffraction analysis from the Canterbury Basin, Expedition 317. In Fulthorpe, C.S., Hoyanagi, K., Blum, P., and the Expedition 317 Scientists, Proc. IODP, 317: Tokyo (Integrated Ocean Drilling Program Management International, Inc.).

doi:10.2204/iodp.proc.317.205.2014

${ }^{2}$ Department of Geological Sciences, University of Florida, PO Box 112120, Gainsville FL 32611, USA. Correspondence author: jmjaeger@ufl.edu

\section{Abstract}

This report describes the mineral assemblages from four sites in the Canterbury Basin, eastern South Island, New Zealand. Coring was completed during Expedition 317 of the Integrated Ocean Drilling Program. A total of 838 unlithified samples of continental margin lithologies (mud, sand, shell hash, and marl) were analyzed by X-ray diffraction (qXRD) using random powder mounts of bulk samples. Sample analyses primarily targeted seismic sequences S16-S19 at all four sites (U1351-U1354), with secondary emphasis on samples with complementary downhole petrophysical data. The primary minerals observed above analytical confidence limits ( $3 \%$ by weight) were, in order of relative abundance, plagioclase (albite + oligoclase + labradorite; $25 \mathrm{wt} \%$ ), illite + muscovite $(\sim 24 \mathrm{wt} \%)$, quartz $(\sim 17 \mathrm{wt} \%)$, chlorite $(\sim 13 \mathrm{wt} \%)$, and calcite + aragonite $(\sim 7 \mathrm{wt} \%)$. Also observed above detection limits were K-feldspar (orthoclase + microcline), epidote, amphiboles (hornblende), and biotite. Total carbonates vary the most at all four sites, ranging in relative abundance from 0 to $77 \mathrm{wt} \%$, with the largest variability at Site U1352. Comparison of carbonate concentrations measured by coulometer and qXRD on co-located samples resulted in an $R^{2}$ value of $0.96(n=194)$ over the full range of values. Spatially, the feldspars (plagioclase and K-feldspar) and quartz were on average the most abundant at the innermost shelf Site U1353 ( 50 wt\%) but were still significant components at the upper slope Site U1352 ( 47 wt\%). Average illite + muscovite + chlorite concentrations were highest at Site U1352 ( 44 wt \%) but were still a significant component $(\sim 35 \mathrm{wt} \%)$ at Site U1353. Prominent changes in mineralogy were not observed across lithostratigraphic unit boundaries, attesting to the gradual transition in lithofacies during progressive seaward margin development. Within lithostratigraphic units, notable changes in mineralogy, primarily between siliciclastic and carbonate minerals, are observed at the projected depths of seismic sequence boundaries. Transitions in the relative abundances of each mineral are often seen within seismic sequence intervals and are the largest in the uppermost two to four sequences (S16-S19).

\section{Introduction}

The primary objective of Integrated Ocean Drilling Program (IODP) Expedition 317 to the Canterbury Basin, South Island, New Zealand, was to sample and date clinoform seismic sequence boundaries and sample associated facies to establish eustatic 
amplitudes (see the "Expedition 317 summary" chapter [Expedition 317 Scientists, 2011a]). Recognition of seismic sequence boundaries within core requires integration of lithostratigraphy, biostratigraphy, sediment composition, physical properties, and geochemistry, as key surfaces (unconformities, maximum flooding surfaces, etc.; Catuneanu, 2006) can only be identified through a multiproxy investigation. Shipboard analyses indicated that shelf and upper slope strata at all sites contained recurring heterolithic facies assemblages in the uppermost strata that transitioned downcore into a more homogeneous strata (see the "Expedition 317 summary" chapter [Expedition 317 Scientists, 2011a]). Additionally, the margin seismic stratigraphy reveals a strongly alongmargin transport in the Miocene-Pliocene that gradually becomes strongly across-margin during the higher amplitude eustatic cycles of the Pleistocene (Fulthorpe and Carter, 1991; Lu and Fulthorpe, 2004; Lu et al., 2003). The regional geology of South Island changes systematically along-margin, providing a means by which to petrologically differentiate (fingerprint) dispersal pathways active during different stages of stratal formation (Fig. F1). The Clutha River, which drains the Otago region south of the study area, has a dominantly schist provenance, with arkosic sand mainly composed of quartz, albite, muscovite, biotite, chlorite, and epidote sourced from the schist (Mackinnon, 1983; Mortimer and Roser, 1992; Shapiro et al., 2007). The major rivers west and north of the Expedition 317 drilling transect drain mainly Torlesse terrane, which is composed of graywackedominated turbidite sequences with quartzofeldspathic (both K-feldspar and plagioclase) sandstone, with some argillite and conglomerate and lesser amounts of lawsonite, prehnite, and pumpellyite (Adams and Kelley, 1998; Mortimer, 1993). We have conducted quantitative X-ray diffraction (qXRD) analysis on samples from the four sites drilled during Expedition 317 to provide constraints on sediment composition, which influences the observed lithostratigraphy, sequence stratigraphy, physical properties, and geochemistry. Because there is a strong contrast in the lithology of the potential sediment sources (Torlesse vs. Haast [Otago] schist), quantitative mineralogy also may provide insight into the sediment dispersal processes during margin formation (Andrews and Eberl, 2007; Andrews et al., 2010).

\section{Methods}

\section{Quantitative methods in powder X-ray diffraction analyses}

Sediment mineralogy can be easily studied in the coarse fraction by petrographic analyses (Tucker,
1988). However, quantitative mineralogy of the bulk fraction (sand- to clay-size material) can be analyzed with a range of methods (Omotoso et al., 2006; Ortiz et al., 2009; Tucker, 1988), with powder qXRD analyses considered more robust (Moore and Reynolds, 1997; Tucker, 1988). Yet this method poses challenges primarily associated with producing a sample that has small and homogeneous grain size and is randomly orientated (Eberl, 2003, 2004; Kleeberg et al., 2008; Omotoso et al., 2006; Środoń et al., 2001).

Here we use a qXRD method (RockJock; Eberl, 2003) that uses an internal corundum standard with a sample preparation technique by Środoń et al. (2001) that homogenizes the sample and minimizes preferred orientation (Eberl, 2003). This sample preparation, analysis, and data reduction techniques have been used for several sediment provenance studies (Andrews and Eberl, 2007, 2011, 2012; Eberl, 2004; Ortiz et al., 2009). The procedures that we followed for this work incorporate several changes in sample preparation and data analysis (i.e., RockJock revision 11) that have been implemented by D. Eberl from earlier versions (Eberl, 2003), improving the random orientation of the sample grains as well as the analysis of the diffraction pattern.

The method was implemented and tested before the analysis of sediment samples from the expedition. We prepared several standards of known mineralogy (Table T1) that contained different ratios of the minerals expected to be most abundant in the sediment from Canterbury Basin. Because the presence of muscovite and chlorite in the sediment has shown to be key in identifying sediment sources within the basin (Adams and Kelley, 1998; Mortimer, 1993; Shapiro et al., 2007), sample standards were created containing these minerals. Average accuracy errors for individual minerals using this method are, after normalization, $3 \mathrm{wt} \%$ for quartz, $2 \mathrm{wt} \%$ for albite, $2 \mathrm{wt} \%$ for labradorite, $2 \mathrm{wt} \%$ for orthoclase, $5 \mathrm{wt} \%$ for biotite, $6 \mathrm{wt} \%$ for chlorite, $3 \mathrm{wt} \%$ for muscovite, and $2 \mathrm{wt} \%$ for calcite (Table T2). An overall average error from all standard analyses of $\pm 3 \mathrm{wt} \%$ is the same as that observed by Eberl (2003) and is considered robust enough for comparison with other data sets (e.g., geochemistry, downhole petrophysics logs).

Precision of the method was tested by the analysis of three different splits of a particular sediment sample (Table T3). Each split was taken from an individual sample that went through all steps of sample preparation. Standard deviation between the three replicates' mineralogy show that average errors are $<1 \mathrm{wt} \%$ (after normalization), except in the case of illite, in which precision error is slightly higher (Table T3). 


\section{Sample preparation}

Our sample preparation methods follow those of Eberl (2003; RockJock revision 11), and the reader is directed there for additional specifics and sources of standards/chemicals used. The method used $1 \mathrm{~g}$ of bulk freeze-dried sediment sample that is mixed with $0.25 \mathrm{~g}$ of a corundum standard (nominal grain size $=$ $3.5 \mu \mathrm{m})$. The sample was mixed with $4 \mathrm{~mL}$ of ethanol and ground in a McCrone micronizing mill ( $\mathrm{ZrO}$ cylinders) for $5 \mathrm{~min}$. The sample was then oven dried for $48 \mathrm{~h}$ at $40^{\circ} \mathrm{C}$, after which it was mixed with Vertrel (SPEX CertiPrep) and shaken in a plastic vial with three plastic balls in a vertical vortex for $10 \mathrm{~min}$ to homogenize the sample and minimize the potential for a preferred mineral orientation. The sample was sieved through a $250 \mu \mathrm{m}$ mesh and side-loaded by tapping into a round aluminum sample holder mounted against 600 grit sandpaper. This mounting technique minimizes a preferred mineral orientation (Eberl, 2003; Środoń et al., 2001).

\section{X-ray diffraction parameters and data analysis}

Side-packed samples were loaded onto a sampleholder carousel and were analyzed in a Rigaku Ultima IV X-ray diffraction system operated at $45 \mathrm{kV}$, $35 \mathrm{~mA}$, in which the incidence angle spanned from $5^{\circ}$ to $85^{\circ} 2 \theta$ at $0.02^{\circ} 2 \theta$ step size with a scan speed of $0.5 \mathrm{~s} / \mathrm{step}$, resulting in 4000 data points (Fig. F2). Sample holders were rotated at $10 \mathrm{rpm}$ during a scan. Each sample was analyzed three times to improve the signal-to-noise ratio, and the combined scans were then imported into the Microsoft Excel RockJock macro program (Eberl, 2003). This program uses stored XRD patterns of mineral standards to recreate the measured diffraction pattern. After selecting the minerals that may be present in the sample (Table T4), the diffraction pattern was analyzed using full-pattern fitting in the $19.0^{\circ}$ to $64.5^{\circ} 2 \theta$ range to find integrated intensities for the minerals, which were determined from the proportion of each of the mineral standard pattern that results in the best fit. The process utilizes the Solver function in Excel to minimize the degree of fit parameter between the calculated and measured pattern, with values $<0.1$ considered optimal (Eberl, 2003). Our average degree of fit was 0.097, with a standard deviation of 0.011 (Table T4). The integrated intensities of the mineral standards were used as a reference to determine the weight percentages of the minerals in the sample. The output of this program included a list of minerals studied with their corresponding weight percent and degree of fit (Table T5).

In describing concentrations, mineral groups were presented in the report. Some minerals considered in the diffraction pattern analysis were included to account for variability in the shipboard observed mineralogy of Expedition 317 sediment. This was the case for biotite, which generally was not observed in pattern analysis (Table T5) but was observed visually in smear slides (see the "Expedition 317 summary" chapter [Expedition 317 Scientists, 2011a]). Consequently, the biotite content of the analyses samples may have been reflected in the combined concentrations of biotite, phlogopite, which has a similar diffraction pattern to biotite, and glauconite (only observed in samples from Hole U1351B), which may be a product of biotite alteration. Several polytypes of illite were included in the RockJock analysis, but to be conservative we combined them with muscovite because of the similarity in patterns (Moore and Reynolds, 1997), although it is reported as separate phases in Table T5. Plagioclase feldspars are reported as a total amount, and the most abundant phase observed was albite, with lesser amounts of oligoclase ( $25 \%$ of total plagioclase feldspars), and trace amounts of labradorite. K-feldspars are reported as a total amount with roughly equal amounts of orthoclase and microcline, when present.

\section{Results}

The sampling strategy for quantitative mineralogy analysis was to collect one sample from each major lithology in each $10 \mathrm{~m}$ long core, with as many as three samples taken per core shipboard and additional samples taken at the repository after the expedition as necessary to capture the range in lithology per core. The primary sample taken shipboard was co-located with a smear slide sample and as close as possible to samples collected for clay mineral analyses and bulk carbonate analyses, the latter of which was done shipboard. Shipboard bulk-powder XRD analyses were performed on the primary sample taken in each core and are described in the site chapters (see the "Site U1351," "Site U1352," "Site U1353," and "Site U1354" chapters [Expedition 317 Scientists, 2011b, 2011c, 2011d, 2011e]). Results of postexpedition $\mathrm{qXRD}$ are tabulated in Table $\mathrm{T} 5$. The primary focus of postexpedition analyses described here was to determine the mineralogical composition of unlithified samples collected at all four locations that spanned the uppermost four seismic sequences (S16-S19), as core recovery was highest in these sequences (see the "Expedition 317 summary" chapter [Expedition 317 Scientists, 2011a]). A secondary priority was to analyze unlithified samples from depth intervals that had corresponding downhole logging data. This was done to allow for further interpretation of downhole logging data in terms of 
sediment mineralogy; the primary sites for accomplishing this were Sites U1351-U1354. Additional unlithified samples from Hole U1352B below the logging depth (Subunit IIA) were analyzed to validate visually observed mineralogy trends. A brief synopsis of spatial and temporal variations in mineral abundance is presented below by site and lithostratigraphic unit.

\section{Comparison with shipboard carbonate analyses}

To evaluate the accuracy of the sample preparation and data processing technique, carbonate mineral abundances determined by qXRD using the RockJock technique were compared with shipboard measurements of total carbonate based on coulometer measurements (see the "Expedition 317 summary" chapter [Expedition 317 Scientists, 2011a]). Carbonates are a common choice for evaluation of the sample preparation and data analysis techniques used here (Andrews and Eberl, 2007; Eberl, 2004). Comparison of the two methods resulted in an $R^{2}$ value of $0.96(n=194)$, indicating considerable correlation between the two methods (Fig. F3). The agreement between the two methods holds over the entire range of carbonate mass percentages determined with the coulometer (5\%-25\%; Fig. F3). The maximum offset in terms of slope is 5\% (slope = 1.05 ) for samples $<10 \%$ carbonate (coulometer), with coulometer results higher than qXRD results by $2.5 \%$ (Fig. F3). This magnitude of difference may simply reflect lithologic/compositional heterogeneity between samples used for qXRD and coulometry.

\section{Site U1351}

The main objectives of coring at Site U1351 were to sample facies landward of but proximal to clinoformal rollovers of progradational sequence boundaries U8-U19; to sample slope facies of boundaries U4-U7 to provide age control; and to generally characterize facies, paleoenvironments, and depositional processes associated with the sequence stratigraphic model and correlate with seismic stratigraphic models (see the "Site U1351" chapter [Expedition 317 Scientists, 2011b]). Recovery was hampered by the presence of two problematic lithologies: (1) beds of presumably unlithified shell and sand in Unit I, some of which was recovered, and (2) likely high concentrations of silt in Unit II. Two lithostratigraphic units were identified that reveal downhole changes in margin sedimentation processes and paleoenvironments from an inner middle shelf setting (Unit I) to an outer shelf-upper slope setting (Unit II). The primary lithologies of Unit I are fossiliferous mud and sandy mud, very fine to medium well-sorted sand, muddy sand, mud (high clay content), and shell hash (Fig. F4A) that spans from modern to early Pliocene. Visually identified sand- and silt-size grains are dominated by quartz and feldspar, with common to rare mica (biotite and muscovite), chlorite, ferromagnesian minerals (various amphiboles), other dense minerals (zircon, clinozoisite, epidote, tourmaline, and others), and glauconite. Shipboard XRD analyses support these observations. Postexpedition analyses revealed that the most abundant minerals (median value) in Unit I are illite + muscovite (26 wt\%), followed by plagioclase (albite; $24 \mathrm{wt} \%)$, quartz (15 wt\%) and chlorite (15 wt\%), total carbonates (5 wt\%), and K-feldspar (4 wt\%) (Table T5; Figs. F4, F5). Minerals that are occasionally observed above the $3 \mathrm{wt} \%$ minimum concentration include biotite. The carbonate minerals aragonite and calcite show the greatest variability within this unit (Figs. F4B, F5). Other mineral phases that could be characteristic of a Torlesse source (i.e., prehnite) were not detected above the $3 \mathrm{wt} \%$ threshold in this or any other lithostratigraphic unit in the expedition (Table T5). Mineralogy often changes noticeably (especially from carbonate to siliciclastics) across depths that corresponded with seismic sequence boundaries, and the greatest variability in downhole mineralogy is in the intervals corresponding to seismic sequences S16-S19 (Fig. F4).

Unit II is early Pliocene to late Miocene in age and is composed of mud and very fine sandy mud, both occasionally shell bearing, with minor amounts of very fine muddy sand (Fig. F4). Incipient to well-developed authigenic carbonate cementation is observed as cemented intervals (nodules and concretions). Recovery in this unit was poor, so lithologic trends with depth are ambiguous, but the lowermost part of Unit II contains slightly more calcareous sandy mud. The composition and mineralogy of Unit II is similar to that of Unit I, but the visually described carbonate content is less variable in Unit II; glauconite is less concentrated in this unit; and quartz, feldspar, and illite + muscovite as seen in shipboard XRD analyses are less variable. Postexpedition qXRD analyses support these observations (Table T5; Figs. F4, F6). The most abundant mineral (median value) in Unit II is quartz (26 wt $\%)$, followed by plagioclase (25 wt\%), illite + muscovite $(20 \mathrm{wt} \%)$, chlorite $(11 \mathrm{wt} \%)$, and total carbonates ( $8 \mathrm{wt} \%)$. Minerals that are occasionally observed above the $3 \mathrm{wt} \%$ minimum concentration include K-feldspar, epidote, and biotite. Quartz shows the greatest variability within this unit (Figs. F4, F6).

The boundary between Units I and II is a transitional interval between 247 and 300 meters below seafloor (mbsf) in lithofacies, biofacies, and downhole logging 
data. Postcruise qXRD results cannot definitively place a single transition point, although quartz concentrations are higher below this transition (Fig. F4A).

\section{Site U1352}

The main objectives of coring at Site U1352 were to sample slope sediments basinward of clinoform breaks of progradational seismic sequence boundaries that can provide sequence boundary ages; to penetrate the Marshall Paraconformity and the top of the underlying Amuri limestone; and to describe sedimentary processes in an slope-basin setting where contour currents are active but where obvious sediment drift geometries observed in seismic data are absent (see the "Site U1352" chapter [Expedition 317 Scientists, 2011c]). Recovery at the site varied between holes, with a reduction in intervals that represented a transition between lithified and unlithified lithologies. The site contained three lithostratigraphic units. Unit I spans the Holocene to middle Pliocene and is composed of three subunits. Subunit IA is primarily muddy facies composed of calcareous sandy mud; interbedded sand, mud, and clay; massive sand; mottled sandy mud; homogeneous mud; shelly mud; and marl (Fig. F7A). Visually identified sand- and silt-size grains are quartz, feldspar, rock fragments, mica (mostly muscovite), ferromagnesian minerals (hornblende), and dense minerals (epidote and zircon). Authigenic minerals include pyrite in the upper part of the subunit and microcrystalline carbonate in the lower part of the subunit and in cemented zones. Shipboard XRD data support these observations with the exception of a lack of the minor authigenic phases such as pyrite. From postexpedition qXRD analyses, the most abundant mineral (median value) in Subunit IA is illite + muscovite (28 wt\%), followed by plagioclase (27 wt\%), quartz (20 wt\%), chlorite (14 wt\%), and K-feldspar (4 wt\%). (Table T5; Figs. F7A, F8). Minerals that are occasionally observed above the $3 \mathrm{wt} \%$ minimum concentration include total carbonates and show the greatest variability within this unit (Figs. F7B, F8). In contrast to the shelf site, mineralogy does not change noticeably across depths that corresponded with seismic sequence boundaries, and no downhole trends in mineralogy are observed within the intervals corresponding to seismic sequences (Fig. F7).

Subunit IB is primarily mud, sometimes rich in shell. Secondary lithologies include calcareous very fine to fine sand, sandy mud, and muddy sand intercalated with the mud. Visually identified minerals are similar to Subunit IA but with a greater concentration of carbonates, and shipboard XRD analyses support these observations and include a noticeable decrease in quartz deeper in this subunit. From postexpedition qXRD analyses, the most abundant mineral (median value) in Subunit IB is illite + muscovite (29 wt\%), followed by plagioclase (25 wt \%), quartz (16 wt \%), chlorite (16 wt\%), K-feldspar (4 wt\%), and total carbonates (4 wt\%) (Table T5; Figs. F7, F9). Minerals that are occasionally observed above the $3 \mathrm{wt} \%$ minimum concentration include amphibole. Total carbonates show the greatest variability within this unit (Figs. F7, F9). As in Subunit IA, mineralogy does not change noticeably across depths that corresponded with seismic sequence boundaries, although the boundaries tend to be relatively enriched in carbonates and deficient in siliciclastics. As in Subunit IA, no downhole trends in mineralogy are observed within the intervals corresponding to seismic sequences (Fig. F7).

Subunit IC is comprised of homogeneous mud, calcareous sandy mud and sandy marl, and sandy marlstone (Fig. F7), and mineralogy observed visually and in shipboard XRD is similar to the two other subunits but has an obvious higher degree of variability within the subunit. From postexpedition qXRD analyses, the most abundant mineral (median value) in Subunit IC is illite + muscovite (29 wt\%), followed by plagioclase (23 wt\%), quartz (17 wt\%), chlorite $(14 \mathrm{wt} \%)$, total carbonates $(8 \mathrm{wt} \%)$, and $\mathrm{K}$ feldspar (4 wt\%) (Table T5; Figs. F7, F10). Minerals that are occasionally observed above the $3 \mathrm{wt} \% \mathrm{~min}-$ imum concentration include epidote and amphibole. Total carbonates show the greatest variability within this unit (Figs. F7, F10). As in Subunits IA and IB, mineralogy does not change noticeably across depths that corresponded with seismic sequence boundaries, although the boundaries tend to be relatively enriched in carbonates and deficient in siliciclastics. As in Subunits IA and IB, no downhole trends in mineralogy are observed within the intervals corresponding to seismic sequences (Fig. F7).

The lithologic transition between Units I and II is indistinct, reflecting a gradual transition to deeper slope depositional environments. Postexpedition qXRD analyses supports this observation, with no remarkable changes in composition at this break, although chlorite and illite + muscovite concentrations increase and total carbonates decrease upsection across this transition (Fig. F7). Unit II spans the middle Pliocene through early Miocene and is comprised of hemipelagic to pelagic lithologies of calcareous sandy mud, sandy marls, chalk, sandy marlstone, and sandy limestone, with minor amounts of calcareous mudstone and sandstone. A noticeable trend in Unit II is a gradual downhole progression from uncemented bioturbated calcareous sandy mud and marl (Subunit IIA) to lithified marlstone and limestone (Subunit IIB) with a greater abundance of glauconite and dark muddy intervals, current-generated structures, and laminated sandstone beds in Sub- 
unit IIC. Within Unit II, mineralogy that was visually identified and from shipboard XRD minerals is similar to Unit I, but with a reduction in ferromagnesian minerals and quartz deeper in the section. From postexpedition qXRD analyses, the most abundant mineral (median value) in Subunit IIA is total carbonates $(24 \mathrm{wt} \%)$, followed by plagioclase (21 $\mathrm{wt} \%)$, quartz (20 wt\%), illite + muscovite (16 wt\%), and chlorite (10 wt $\%)$ (Table T5; Figs. F7, F11). Minerals that are occasionally observed above the $3 \mathrm{wt} \%$ minimum concentration include K-feldspar. Total carbonates show the greatest variability within this unit.

\section{Site U1353}

The main objectives of coring at Site U1353 were to sample facies landward of clinoformal rollovers of seismic sequence boundaries U5-U19 to estimate paleowater depths in order to evaluate eustatic amplitudes and to investigate the facies, paleoenvironments, and depositional processes at the most landward shelf setting occupied during Expedition 317 (see the "Site U1353" chapter [Expedition 317 Scientists, 2011d]). Core recovery varied at Site U1353 as a function of drilling technique (higher recovery with the advanced piston corer [APC], and very low with the extended core barrel $[\mathrm{XCB}]$ ) and lithology (coarser lithologies were more difficult to recover with considerable downhole contamination by cave-in). The site contained two lithostratigraphic units that transition from a heterolithic upper section with abrupt contacts (Unit I) to a more sedimentary featureless mud-dominated section with depth (Unit II), suggesting a gradual transition in depositional environments during the Pliocenemodern period represented in these cores. Unit I is Holocene to early Pliocene in age, and the primary lithologies are heterolithic facies dominated by a homogeneous mud with trace amounts of very fine sand (Fig. F12A). Secondary lithologies include beds of sandy shelly mud, shell layers to shell hash mixed with abundant bioclastic and siliciclastic materials; well-sorted, very fine, highly micaceous sand; and micaceous, homogeneous sandy marl. The visually determined sediment composition of Unit I is quartz and feldspar, with lesser dense minerals (epidote, amphibole, and zircon), sheet silicates (biotite, muscovite, and chlorite), and rock fragments. Authigenic components include pyrite and other opaque minerals. Mineralogy determined from shipboard XRD analyses is in general agreement with the visually determined composition. From postexpedition qXRD analyses, the most abundant mineral (median value) in Unit I is plagioclase ( $24 \mathrm{wt} \%)$, followed by illite + muscovite (23 wt $\%)$, quartz $(18 \mathrm{wt} \%)$, chlorite
(13 wt\%), total carbonates (6 wt\%), and K-feldspar (5 wt\%) (Table T5; Figs. F12, F13). Minerals that are occasionally observed above the $3 \mathrm{wt} \%$ minimum concentration include epidote and amphibole. Total carbonates show the greatest variability within this unit, although illite + muscovite and quartz also have large ( $30 \mathrm{wt} \%)$ variability (Figs. F12A, F13). As at Sites U1351 and U1354, mineralogy often changes noticeably (especially from carbonate to siliciclastics) across depths that corresponded with seismic sequence boundaries. The greatest variability in downhole mineralogy is within the intervals corresponding to seismic sequences S16-S19, and there is a trend of high carbonate mineral concentration just above seismic sequence boundaries and enrichment in siliciclastics upsection with the sequences (Fig. F12).

The Unit I/II boundary is noted by a transition from heterolithic facies to more homogeneous lithologies below the transition at $151 \mathrm{mbsf}$, and no distinct changes in mineralogy from postexpedition qXRD analyses are apparent (Fig. F12). Unit II is early Pliocene-middle to early Miocene in age and is characterized by its general lithologic uniformity, lacking the clay-rich and marl-rich beds seen in Unit I. The primary lithology of Unit II consists of homogeneous mud with varying amounts of micaceous very fine sand (Fig. F12). The visually documented sediment composition of Unit II is similar to Unit I, with comparable mineralogy, but with noticeably less amounts of hornblende and green ferromagnesian mineral concentrations in the uppermost part of Unit II, which are not observed below 365 mbsf in XRD data. From postexpedition qXRD analyses, the most abundant mineral (median value) in Unit II is quartz (27 wt\%), followed by plagioclase (26 wt\%), illite + muscovite (23 wt \%), chlorite (12 wt $\%)$, and $\mathrm{K}$ feldspar (4 wt\%) (Table T5; Figs. F12, F14). Minerals that are occasionally observed above the $3 \mathrm{wt} \% \mathrm{~min}$ imum concentration include total carbonates and epidote (Fig. F14). Total carbonates show the greatest variability within this unit, although as in Unit I, illite + muscovite and quartz also have large $(\sim 30 \mathrm{wt} \%)$ variability (Figs. F12, F13). Core recovery was reduced in this unit, so it is difficult to discern any obvious compositional changes within or at seismic sequences and boundaries, although coarser sediment at the boundaries are enriched in quartz and carbonates.

\section{Site U1354}

The main objectives of coring at Site U1354 were similar to those at Site U1353: to sample facies landward of clinoformal rollovers of seismic sequence boundaries U5-U19 but at an intermediate position in the shelf portion of the transect to estimate paleowater 
depths in order to evaluate eustatic amplitudes, and to investigate the facies, paleoenvironments, and depositional processes at the most landward shelf setting occupied during Expedition 317 (see the "Site U1354" chapter [Expedition 317 Scientists, 2011e]). As at Site U1353, core recovery varied as a function of drilling technique (higher recovery with APC and very low with XCB) and lithology (coarser lithologies were more difficult to recover). The site contains two lithostratigraphic units, with Unit I being further divided into two subunits. Postexpedition qXRD analyses at this site focused on the S16S19 sequences as sampled primarily in Hole U1354B (Fig. F15). Unit I spans the Holocene to early Pliocene and is distinguished by a very heterogeneous assemblage of muddy facies. Subunit IA is mostly calcareous mud and calcareous sandy mud, shelly marl, and sandy marl (Fig. F15A). Minor lithologies include very fine to fine sand, calcareous silty very fine to fine sand, and clay-rich mud. The visually determined composition is largely quartz and feldspar, micas (including chlorite, muscovite, and occasionally biotite), rock fragments, ferromagnesian minerals (hornblende), and dense minerals (zircon and epidote). Authigenic components include varying amounts of opaque minerals, carbonate, and glauconite. From postexpedition qXRD analyses, the most abundant mineral (median value) in Subunit IA is plagioclase $(23 \mathrm{wt} \%)$, followed by illite + muscovite (22 wt $\%)$, quartz (15 wt\%), chlorite (13 wt\%), total carbonates (12\%), and K-feldspar (4 wt \%) (Table T5; Figs. F15, F16). Minerals that are occasionally observed above the $3 \mathrm{wt} \%$ minimum concentration include epidote (Fig. F16). Total carbonates show the greatest variability within this unit, although illite + muscovite and quartz also have large ( $30 \mathrm{wt} \%)$ variability (Figs. F15, F16). As at Sites U1351 and U1353, the mineralogy often changes noticeably (especially from carbonate to siliciclastics) across depths that corresponded with seismic sequence boundaries. Boundary U17 was not observed in Hole U1354B, but a change in composition at $\sim 51 \mathrm{mbsf}$ is similar to other sequence boundaries and could represent the depth of boundary U17 in this hole (Fig. F15B). The greatest variability in downhole mineralogy is within the intervals corresponding to seismic sequences S16-S19, and there is a trend of high carbonate mineral concentration just above seismic sequence boundaries and enrichment in siliciclastics upsection with the sequences (Fig. F15).

Hole U1354C is offset $20 \mathrm{~m}$ from Hole U1354B and was drilled to advance the hole after severe weather precluded drilling in Hole U1354B. From postexpedition qXRD analyses, the most abundant mineral (median value) in Subunit IA is illite + muscovite
(25 wt\%), followed by plagioclase (23 wt\%), quartz (15 wt\%), chlorite (15 wt\%), total carbonates (11 wt $\%$ ), and K-feldspar (4 wt $\%$ ) (Table T5; Figs. F17, F18). Minerals that are occasionally observed above the $3 \mathrm{wt} \%$ minimum concentration include amphibole (Fig. F18). Total carbonates show the greatest variability within this unit, although illite + muscovite and chlorite also have large ( 20-30 wt $\%)$ variability (Figs. F17, F18).

Subunit IB lithology is less varied than in Subunit IA and is characterized by a more repetitive succession of facies including homogeneous greenish gray mud and greenish gray to gray calcareous sandy mud to sandy marl. Smear slide observations suggest that composition of this unit is similar to Subunit IA but with decreased concentration of ferromagnesian minerals and glauconite. From postexpedition qXRD analyses, the most abundant mineral (median value) in Subunit IB is illite + muscovite (33 wt\%), followed by chlorite $(25 \mathrm{wt} \%)$, plagioclase $(22 \mathrm{wt} \%)$, quartz (16 wt \%), and K-feldspar (4 wt\%) (Table T5; Figs. F17, F19). Minerals that are occasionally observed above the $3 \mathrm{wt} \%$ minimum concentration include total carbonates (Fig. F19). Total carbonates show the greatest variability within this unit, followed by illite + muscovite, although quartz and chlorite also have large (20 wt\%) variability (Figs. F17, F19).

The Unit I/II boundary is noted by a transition from heterolithic facies to more homogeneous lithologies below 250 mbsf, and no distinct changes in mineralogy from postexpedition qXRD analyses are apparent (Fig. F17) except for decreased variability in total carbonates. Unit II is early Pliocene in age and is characterized by its general lithologic uniformity, dominated by gray, homogeneous silty mud with rare scattered shells. Unit II contains fewer calcareous beds than Unit I (Fig. F17). The visually documented sediment composition of Unit II is similar to Unit I, with comparable mineralogy, but with noticeably less amounts of carbonate. From postexpedition qXRD analyses, the most abundant mineral (median value) in Unit II is plagioclase (26wt\%), followed by quartz (25 wt $\%)$, illite + muscovite $(23 \%)$, chlorite (14\%), and total carbonates (4 wt\%) (Table T5; Figs. F17, F20). Minerals that are occasionally observed above the $3 \mathrm{wt} \%$ minimum concentration include Kfeldspar and epidote (Fig. F20). Illite + muscovite show the greatest variability within this unit although quartz also has large $(\sim 20 \mathrm{wt} \%)$ variability (Figs. F17, F20).

\section{Acknowledgments}

This study analyzed samples provided by the Integrated Ocean Drilling Program (IODP). We thank 
Captain Alex Simpson, as well as the drilling crew, laboratory technicians, and fellow scientists aboard the R/V JOIDES Resolution for their untiring effort during IODP Expedition 317. Funding was granted by the Consortium for Ocean Leadership, U.S. Science Support Program (grant T317A28) and the National Science Foundation (grant OCE-1060844) to J.M. Jaeger. K. Parsons, J. Sepulchre, and J. Moss assisted with sample preparation and data reduction. We thank Dr. John T. Andrews, whose comments helped to improve this manuscript.

\section{References}

Adams, C.J., and Kelley, S., 1998. Provenance of PermianTriassic and Ordovician metagreywacke terranes in New Zealand: evidence from ${ }^{40} \mathrm{Ar} /{ }^{39} \mathrm{Ar}$ dating of detrital micas. Geol. Soc. Am. Bull., 110(4):422-432. doi:10.1130/00167606(1998)110<0422:POPTAO>2.3.CO;2

Andrews, J.T., and Eberl, D.D., 2007. Quantitative mineralogy of surface sediments on the Iceland shelf, and application to down-core studies of Holocene ice-rafted sediments. J. Sediment. Res., 77(6):469-479. doi:10.2110/jsr.2007.045

Andrews, J.T., and Eberl, D.D., 2011. Surface (sea floor) and near-surface (box cores) sediment mineralogy in Baffin Bay as a key to sediment provenance and ice sheet variations. Can. J. Earth Sci., 48(9):1307-1328. doi:10.1139/ e11-021

Andrews, J.T., and Eberl, D.D., 2012. Determination of sediment provenance by unmixing the mineralogy of source-area sediments: the "SedUnMix" program. Mar. Geol., 291-294:24-33. doi:10.1016/j.margeo.2011.10.007

Andrews, J.T., Jennings, A.E., Coleman, G.C., and Eberl, D.D., 2010. Holocene variations in mineral and grainsize composition along the East Greenland glaciated margin $\left(\mathrm{ca} 67^{\circ}-70^{\circ} \mathrm{N}\right)$ : local versus long-distance sediment transport. Quat. Sci. Rev., 29(19-20):2619-2632. doi:10.1016/j.quascirev.2010.06.001

Catuneanu, O., 2006. Principles of Sequence Stratigraphy (1st Ed.): Amsterdam (Elsevier).

Davis, J.C., 2002. Statistics and Data Analysis in Geology (3rd Ed.): New York (John Wiley \& Sons).

Eberl, D.D., 2003. User's guide to RockJock: a program for determining quantitative mineralogy from powder Xray diffraction data. Open-File Rep.-U.S. Geol. Surv., 200378. http://pubs.usgs.gov/of/2003/of03-078/

Eberl, D.D., 2004. Quantitative mineralogy of the Yukon River system: changes with reach and season, and determining sediment provenance. Am. Mineral., 89:17841794. http://pubs.er.usgs.gov/publication/70026557

Expedition 317 Scientists, 2011a. Expedition 317 summary. In Fulthorpe, C.S., Hoyanagi, K., Blum, P., and the Expedition 317 Scientists, Proc. IODP, 317: Tokyo (Inte- grated Ocean Drilling Program Management International, Inc.). doi:10.2204/iodp.proc.317.101.2011

Expedition 317 Scientists, 2011b. Site U1351. In Fulthorpe, C.S., Hoyanagi, K., Blum, P., and the Expedition 317 Scientists, Proc. IODP, 317: Tokyo (Integrated Ocean Drilling Program Management International, Inc.). doi:10.2204/iodp.proc.317.103.2011

Expedition 317 Scientists, 2011c. Site U1352. In Fulthorpe, C.S., Hoyanagi, K., Blum, P., and the Expedition 317 Scientists, Proc. IODP, 317: Tokyo (Integrated Ocean Drilling Program Management International, Inc.). doi:10.2204/iodp.proc.317.104.2011

Expedition 317 Scientists, 2011d. Site U1353. In Fulthorpe, C.S., Hoyanagi, K., Blum, P., and the Expedition 317 Scientists, Proc. IODP, 317: Tokyo (Integrated Ocean Drilling Program Management International, Inc.). doi:10.2204/iodp.proc.317.105.2011

Expedition 317 Scientists, 2011e. Site U1354. In Fulthorpe, C.S., Hoyanagi, K., Blum, P., and the Expedition 317 Scientists, Proc. IODP, 317: Tokyo (Integrated Ocean Drilling Program Management International, Inc.). doi:10.2204/iodp.proc.317.106.2011

Fulthorpe, C.S., and Carter, R.M., 1991. Continental-shelf progradation by sediment-drift accretion. Geol. Soc. Am. Bull., 103(2):300-309. doi:10.1130/

0016-7606(1991)103<0300:CSPBSD >2.3.CO;2

Kleeberg, R., Monecke, T., and Hillier, S., 2008. Preferred orientation of mineral grains in sample mounts for quantitative XRD measurements: how random are powder samples? Clays Clay Miner., 56(4):404-415. doi:10.1346/CCMN.2008.0560402

Lu, H., and Fulthorpe, C.S., 2004. Controls on sequence stratigraphy of a middle Miocene-Holocene, currentswept, passive margin: offshore Canterbury Basin, New Zealand. Geol. Soc. Am. Bull., 116(11-12):1345-1366. doi:10.1130/B2525401.1

Lu, H., Fulthorpe, C.S., and Mann, P., 2003. Three-dimensional architecture of shelf-building sediment drifts in the offshore Canterbury Basin, New Zealand. Mar. Geol., 193(1-2):19-47. doi:10.1016/S0025-3227(02)00612-6

Mackinnon, T.C., 1983. Origin of the Torlesse terrane and coeval rocks, South Island, New Zealand. Geol. Soc. Am. Bull., 94(8):967-985. doi:10.1130/00167606(1983)94<967:OOTTTA>2.0.CO;2

Moore, D.M., and Reynolds, R.C., Jr., 1997. X-ray Diffraction and the Identification and Analysis of Clay Minerals (2nd ed.): Oxford (Oxford Univ. Press).

Mortimer, N., 1993. Geology of the Otago schist and adjacent rocks. Map.-Inst. Geol. Nucl. Sci., 7. http:// trove.nla.gov.au/work/30107893

Mortimer, N., and Roser, B.P., 1992. Geochemical evidence for the position of the Caples-Torlesse boundary in the Otago schist, New Zealand. J. Geol. Soc. (London, U. K.), 149(6):967-977. doi:10.1144/gsjgs.149.6.0967

Omotoso, O., McCarty, D.K., Hillier, S., and Kleeberg, R., 2006. Some successful approaches to quantitative mineral analysis as revealed by the 3rd Reynolds Cup contest. Clays Clay Miner., 54(6):748-760. doi:10.1346/ CCMN.2006.0540609 
Ortiz, J.D., Polyak, L., Grebmeier, J.M., Darby, D., Eberl, D.D., Naidu, S., and Nof, D., 2009. Provenance of Holocene sediment on the Chukchi-Alaskan margin based on combined diffuse spectral reflectance and quantitative X-ray diffraction analysis. Global Planet. Change, 68(1-2):73-84. doi:10.1016/j.gloplacha.2009.03.020

Shapiro, S.A., Marsaglia, K.M., and Carter, L., 2007. The petrology and provenance of sand in the Bounty submarine fan, New Zealand. In Arribas, J., Johnsson, M.J., and Critelli, S. (Eds.), Sedimentary Provenance and Petrogenesis: Perspectives from Petrography and Geochemistry. Spec. Pap.-Geol. Soc. Am., 420:277-296. doi:10.1130/ 2006.2420(17)
Środoń, J., Drits, V.A., McCarty, D.K., Hsieh, J.C.C., and Eberl, D.D., 2001. Quantitative X-ray diffraction analysis of clay-bearing rocks from random preparations. Clays Clay Miner., 49(6):514-528. http://ccm.geoscienceworld.org/cgi/content/abstract/49/6/514

Tucker, M.E., 1988. Techniques in Sedimentology: Boston (Blackwell Scientific).

Initial receipt: 10 September 2012

Acceptance: 16 June 2013

Publication: 26 February 2014

MS 317-205 
Figure F1. Study area along South Island, New Zealand, Expedition 317. Significant fluvial drainage basins (sediment sources) are highlighted. Predominant sediment transport patterns are shown by coastal currents and Southland Front. R. = River.

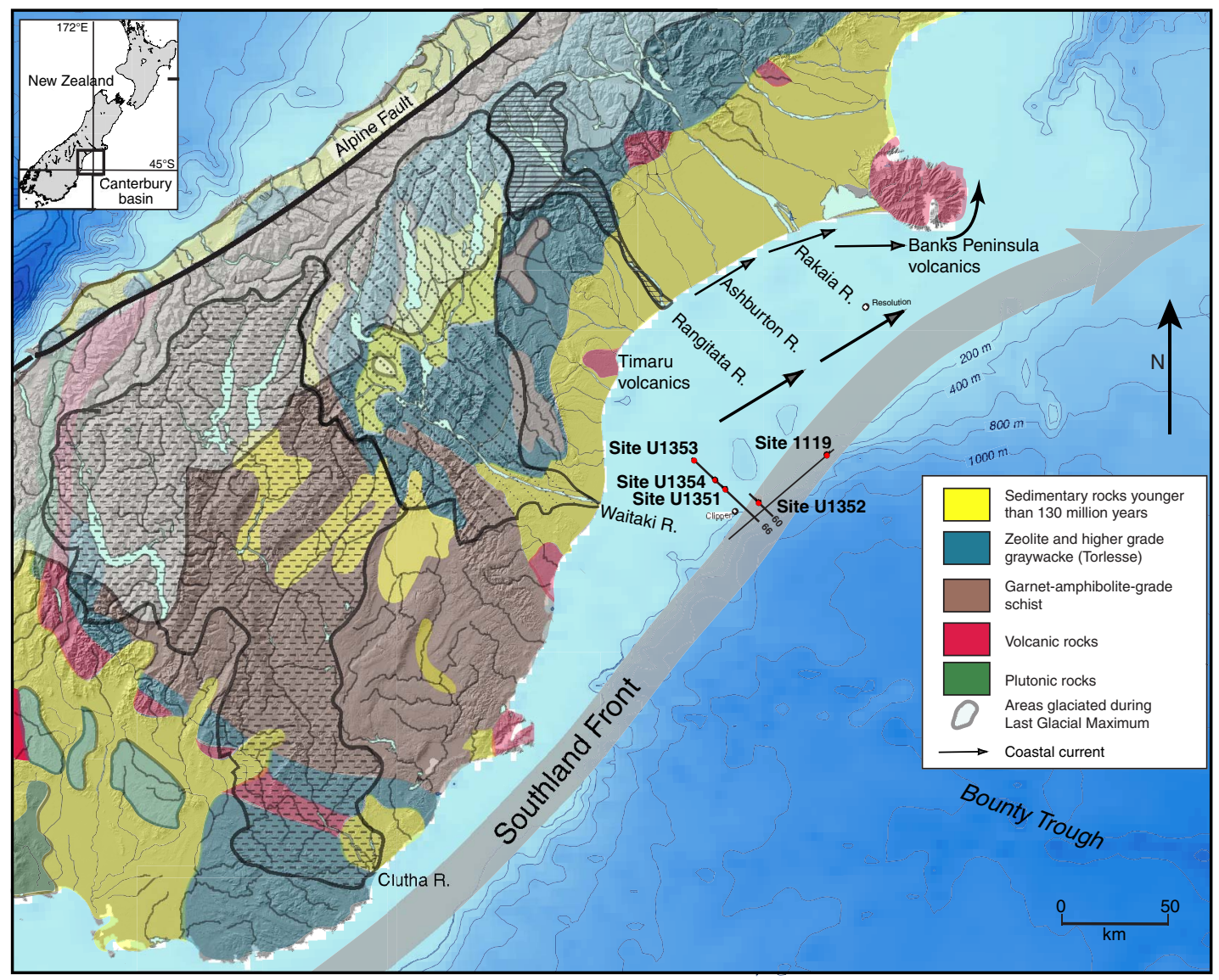


Figure F2. Comparison of measured X-ray diffractogram and calculated best-fit curve obtained from RockJock on two representative samples, Hole U1351B. A. Mica rich. B. Carbonate rich.
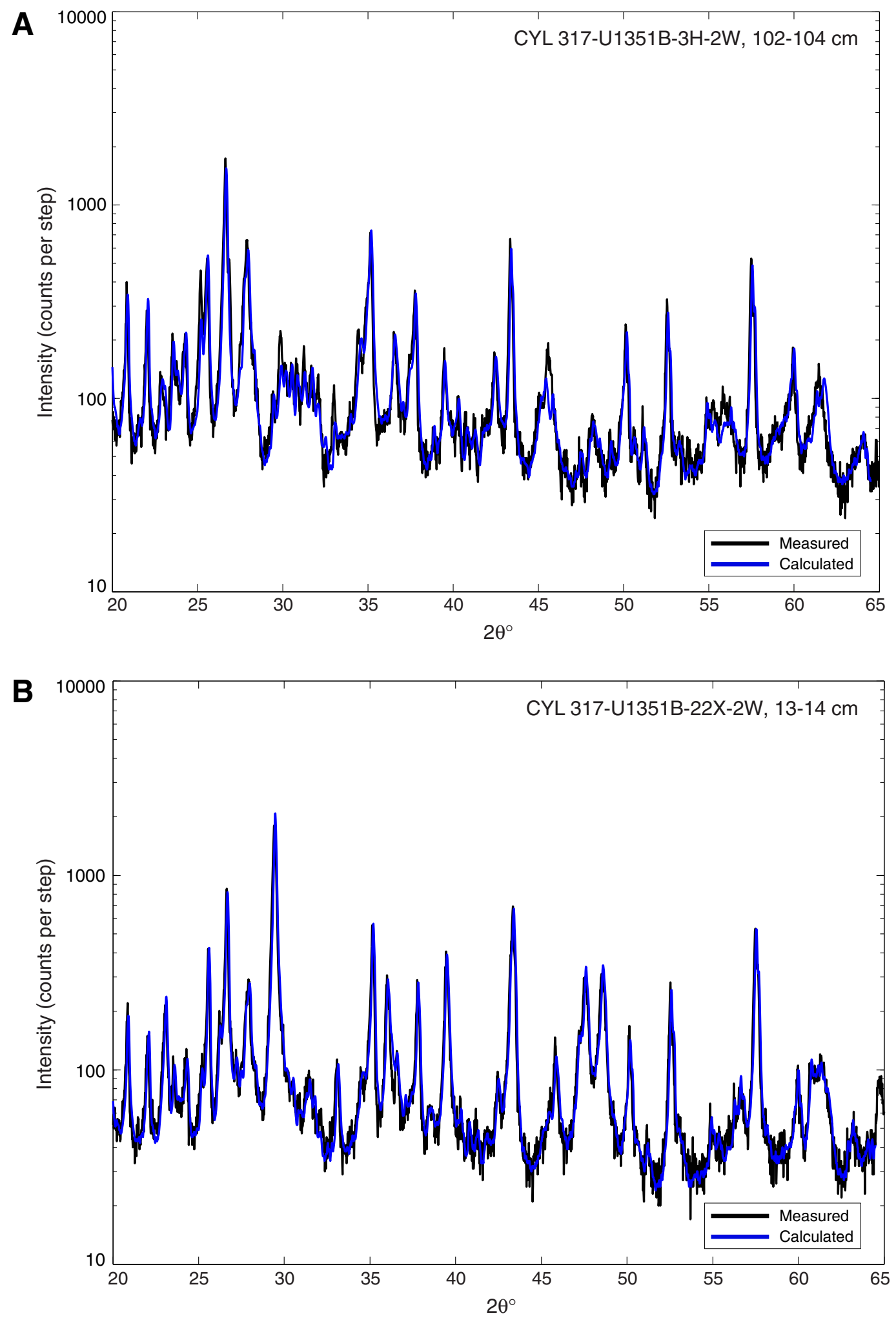
Figure F3. Comparison between X-ray diffraction and coulometer methods for determining carbonate mineral contents in samples, Sites U1351-U1354. A strong correlation with minimal offset (i.e., a slope close to 1) is seen for a range of carbonate concentrations indicating the validity of the RockJock method. Regression performed on data only from that range of concentrations and outliers were not used in the regression, as they likely represent heterogeneity in sample composition (e.g., shell fragment). Coulometer data from sedis.iodp.org.
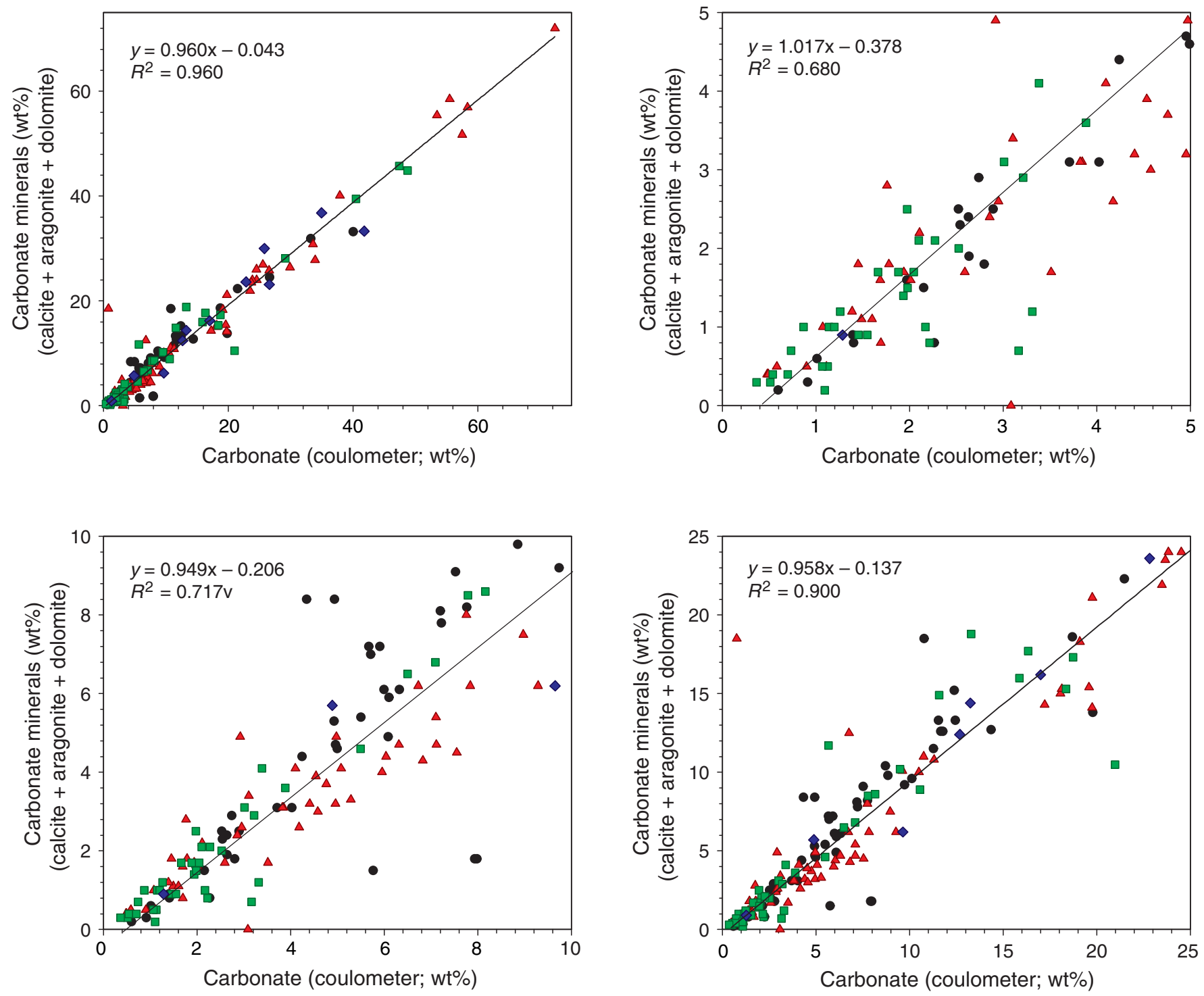

- Site U1351 — Site U1353

$\Delta$ Site U1352 \& Site U1354 
Figure F4. Summary of core recovery, lithology, lithologic units, depositional age, and mineral composition, Hole U1351B. Lithostratigraphic unit boundaries and seismic sequence boundaries from the "Site U1351" chapter (Expedition 317 Scientists, 2011b). A. Primary minerals and mineral groups. Msc = muscovite. (Continued on next page.)

A Hole U1351B

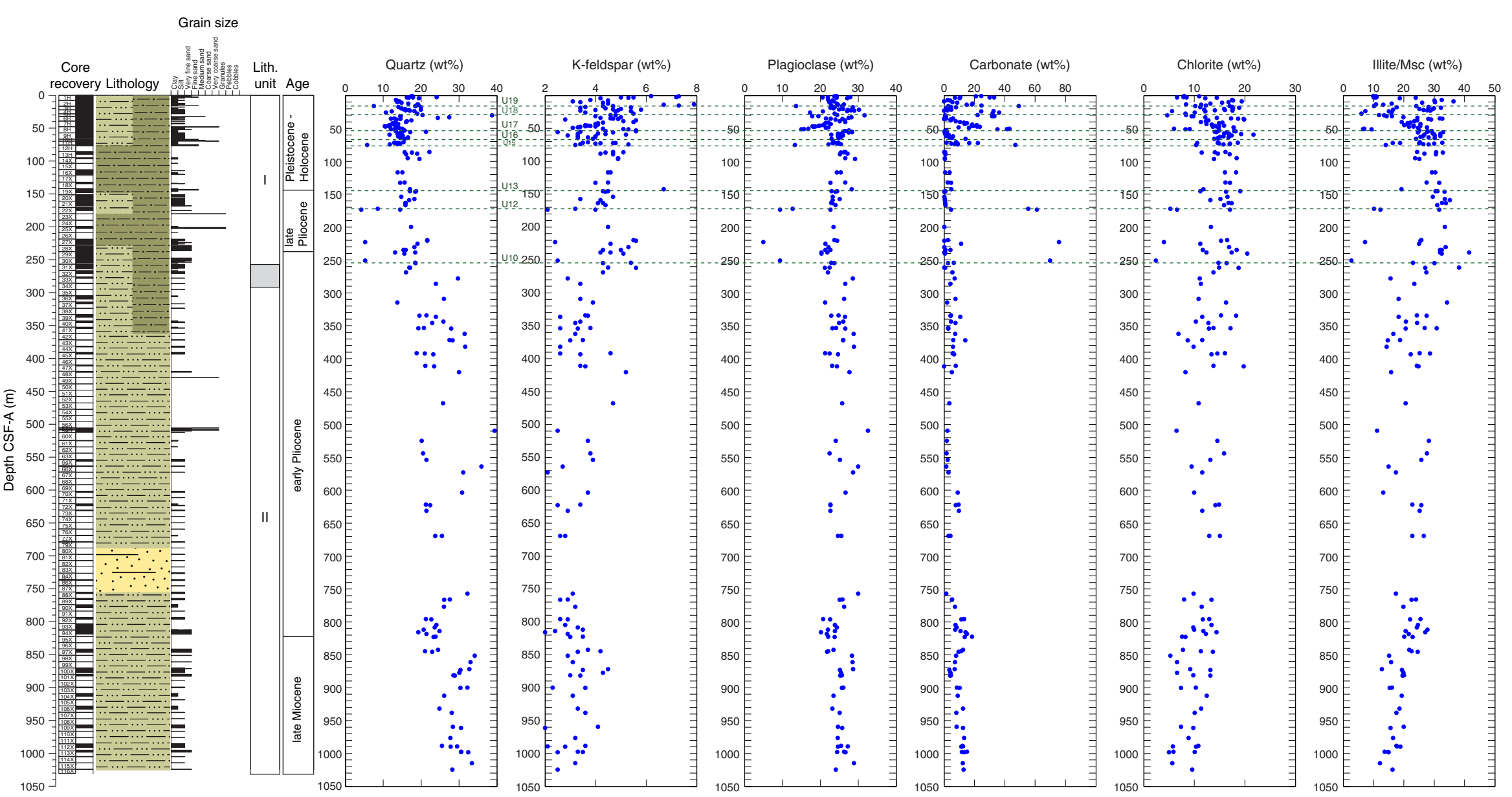

Siliciclastics:
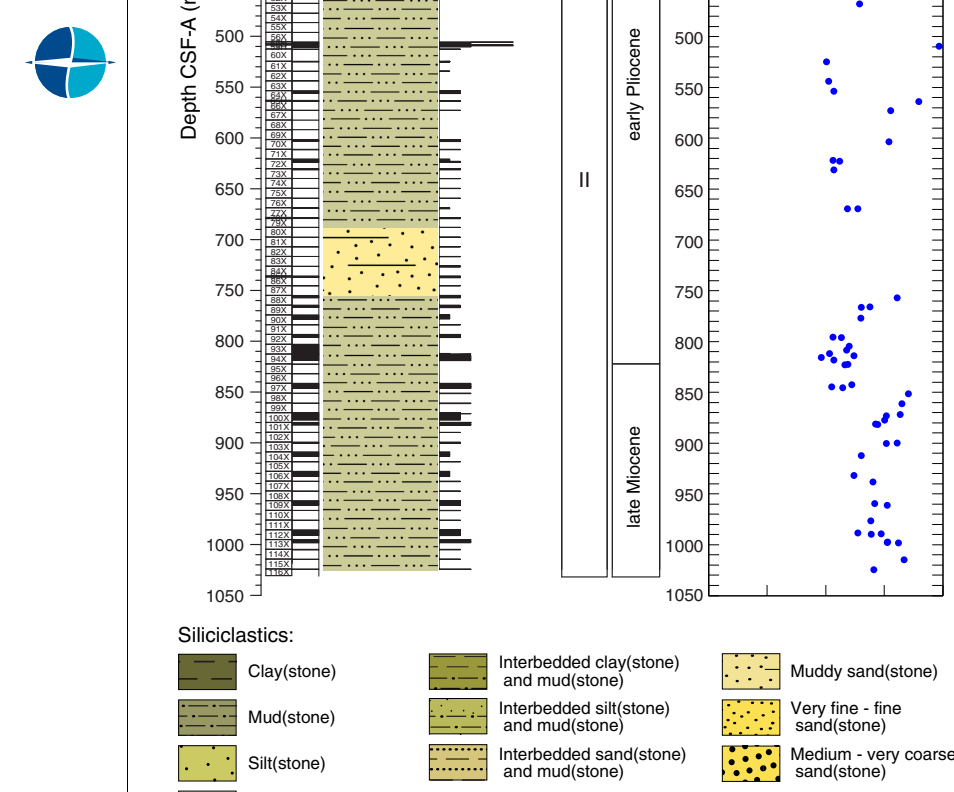

Calcareous:

$\ldots$.... Sandy mud(stone

$\therefore \because:$ Medium - very coarse

Shell hash 
Figure F4 (continued). B. Carbonate minerals.

B Hole U1351B

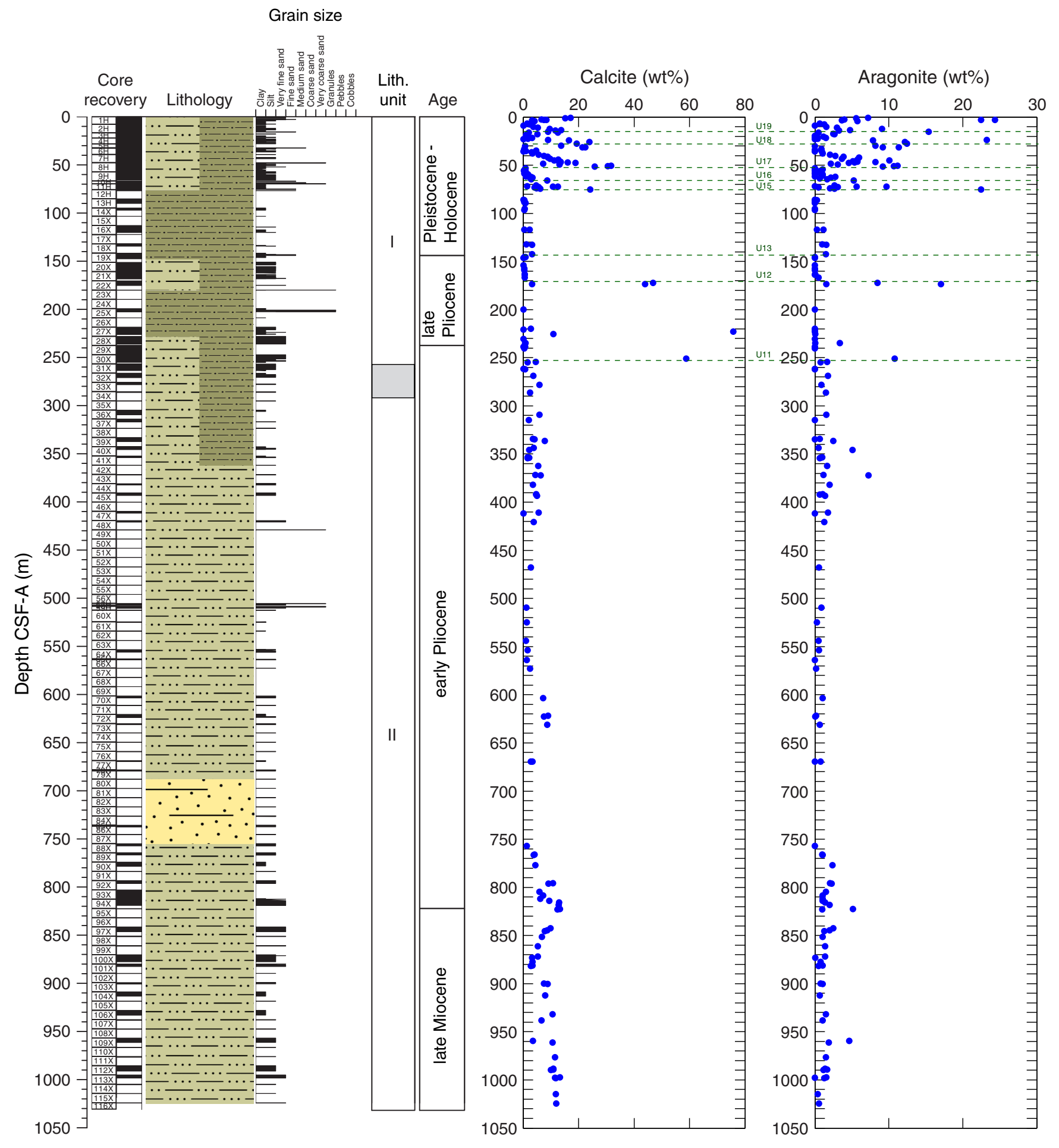


Figure F5. Box plot of the possible primary minerals in Unit I, Hole U1351B. Boxes represents $25 \%$ to $75 \%$ of the population; the horizontal line in the box represents the median value. Lines extending outward from the boxes include the expected normal ranges. Outliers are shown by red crosses (Davis, 2002). Green dashed line is the analytical threshold considered for a valid concentration (3 wt \%). See Table T4 for mineral abbreviations.

Hole U1351B, Unit I

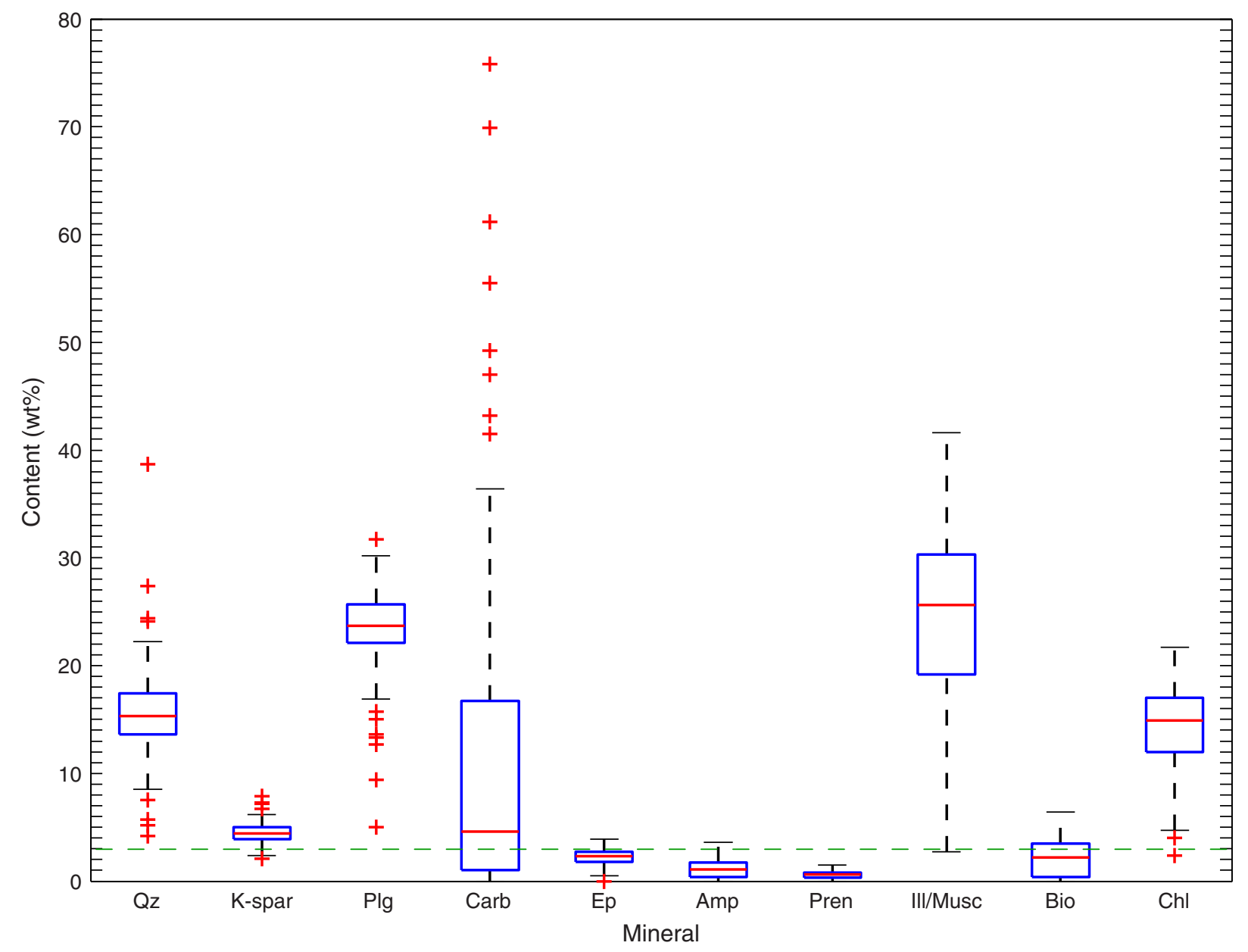


Figure F6. Box plot of the possible primary minerals in Unit II, Hole U1351B. See Figure F5 for explanation of figure. See Table T4 for mineral abbreviations.

Hole U1351B, Unit II

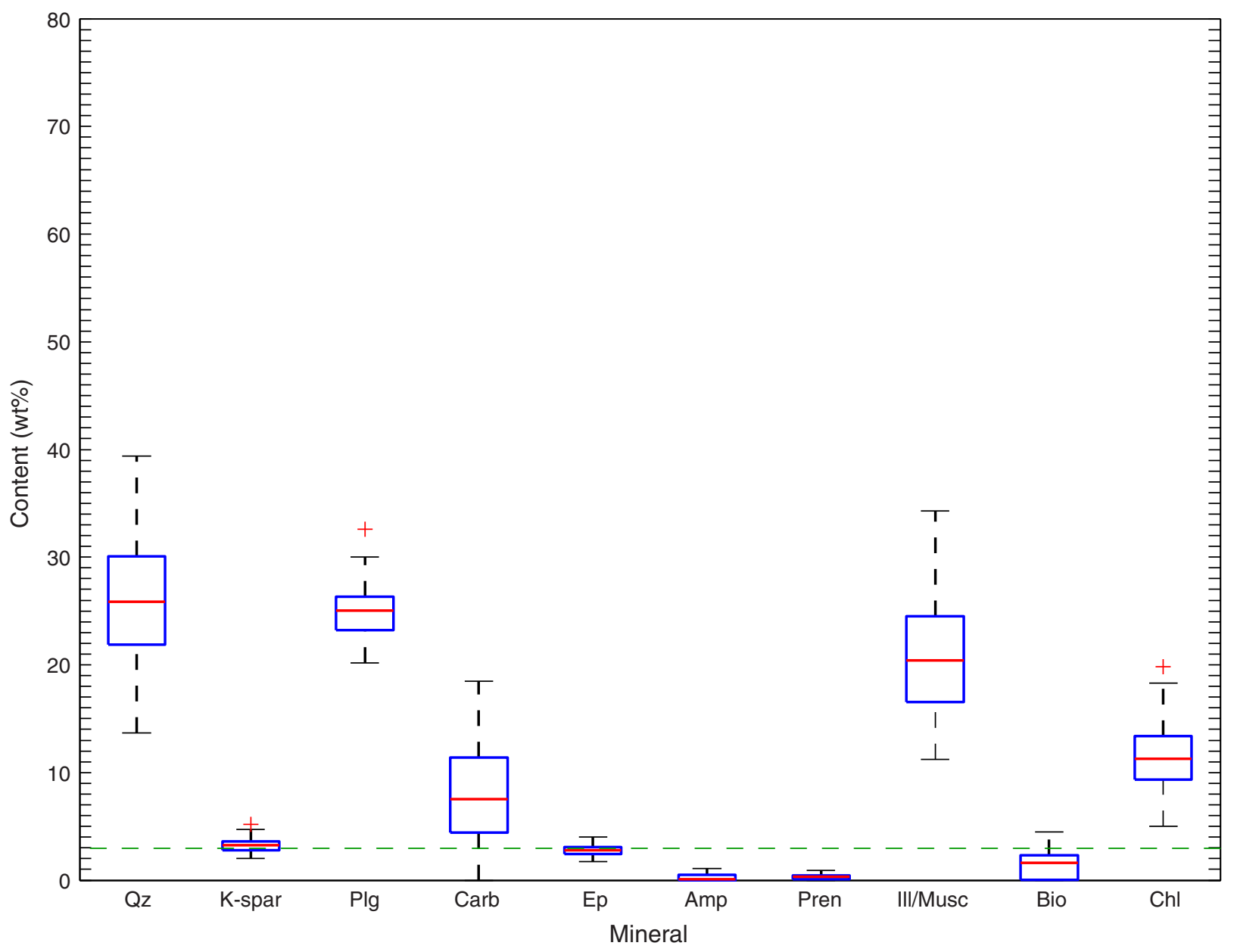


Figure F7. Summary of core recovery, lithology, lithologic units, depositional age, and mineral composition, Hole U1352B. Lithostratigraphic unit boundaries and seismic sequence boundaries are from the "Site U1352" chapter (Expedition 317 Scientists, 2011c). See Figure F4 for explanation of lithology patterns. A. Primary minerals and mineral groups. Msc = muscovite. (Continued on next page.)

A Hole U1352B
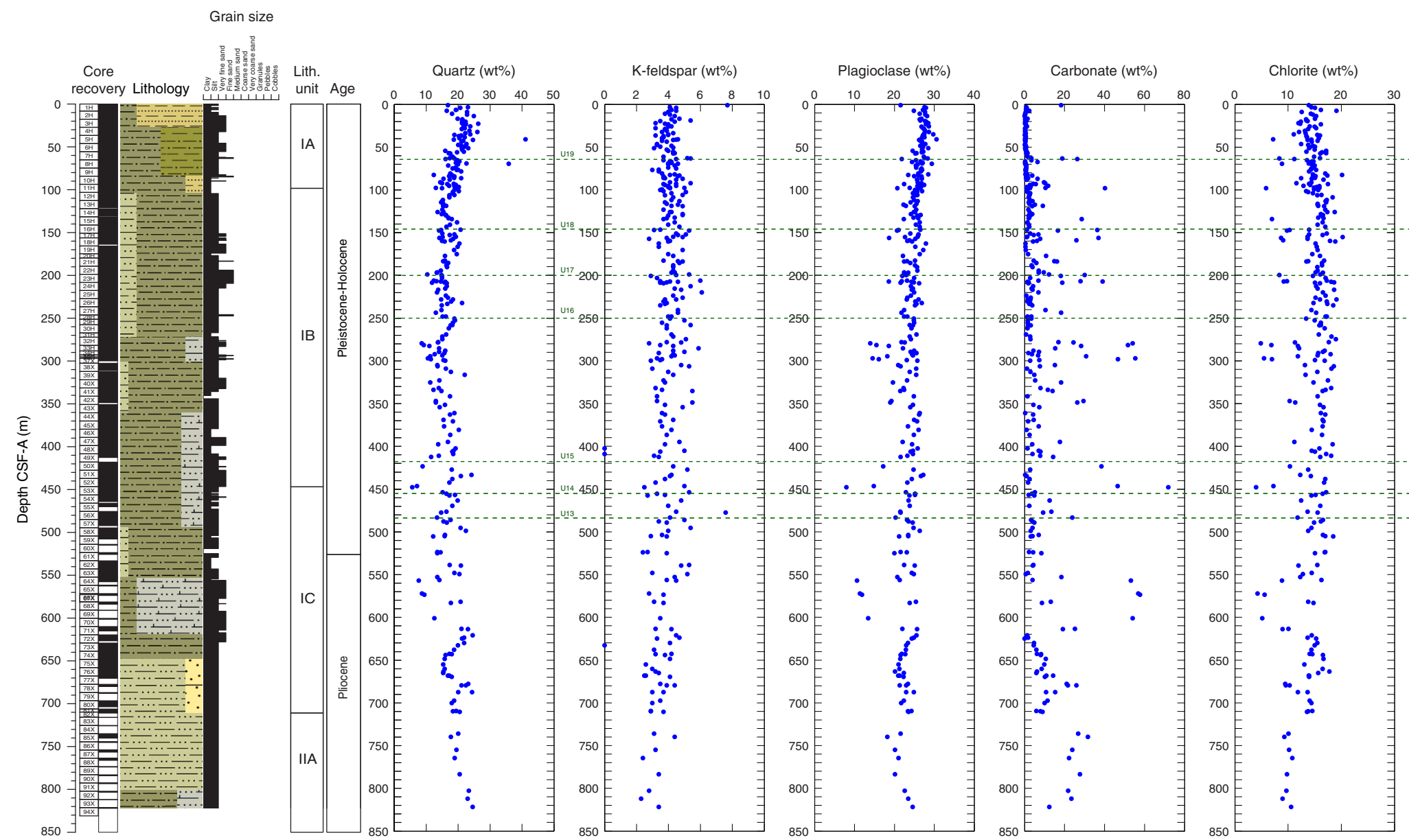

|llite/Msc (wt\%)

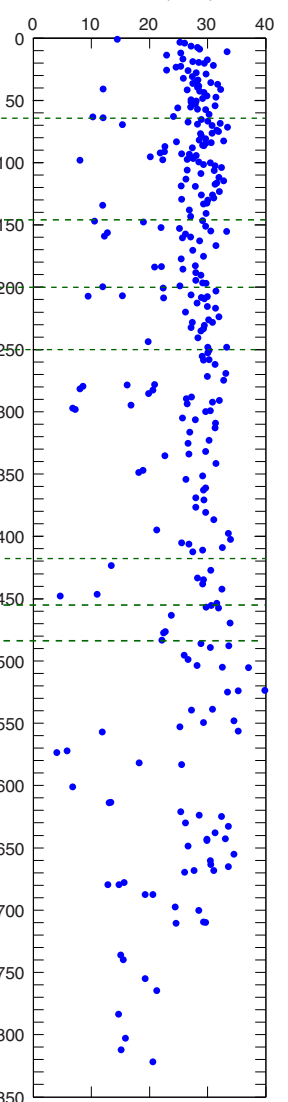


Figure F7 (continued). B. Carbonate minerals.

B Hole U1352B

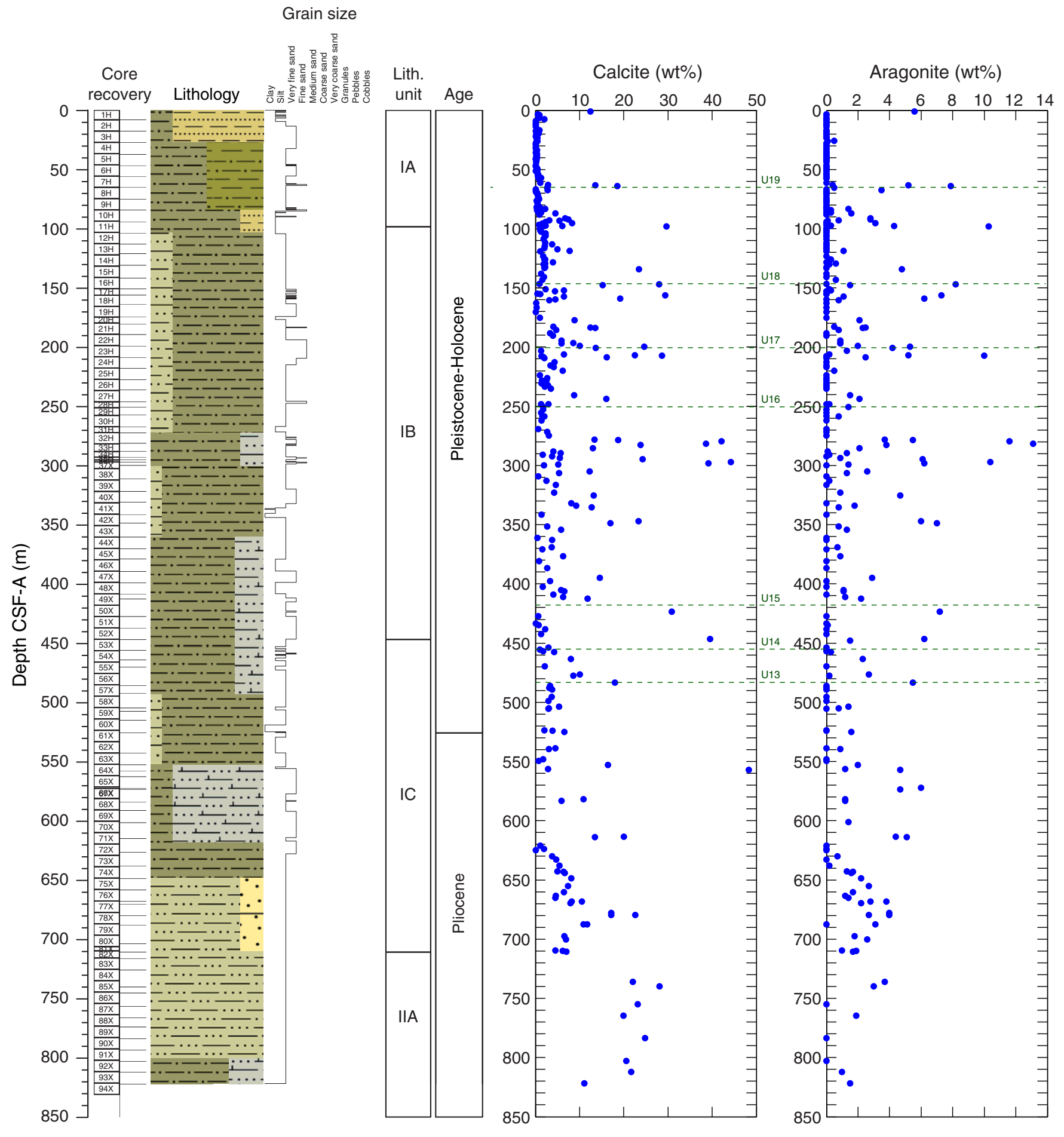


Figure F8. Box plot of the possible primary minerals in Subunit IA, Hole U1352B. See Figure F5 for explanation of figure. See Table T4 for mineral abbreviations.

Hole U1352B, Subunit IA

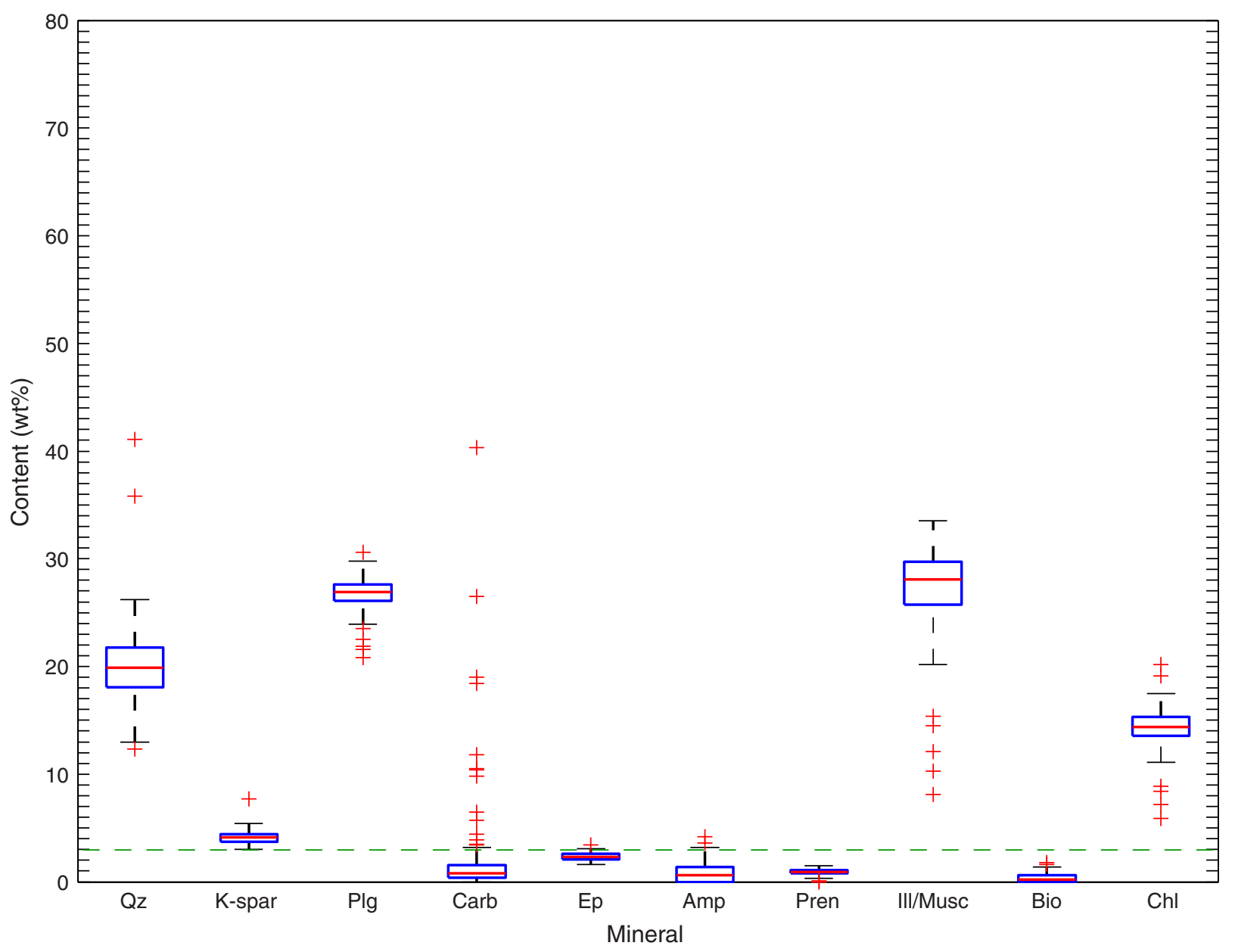


Figure F9. Box plot of the possible primary minerals in Subunit IB, Hole U1352B. See Figure F5 for explanation of figure. See Table T4 for mineral abbreviations.

Hole U1352B, Subunit IB

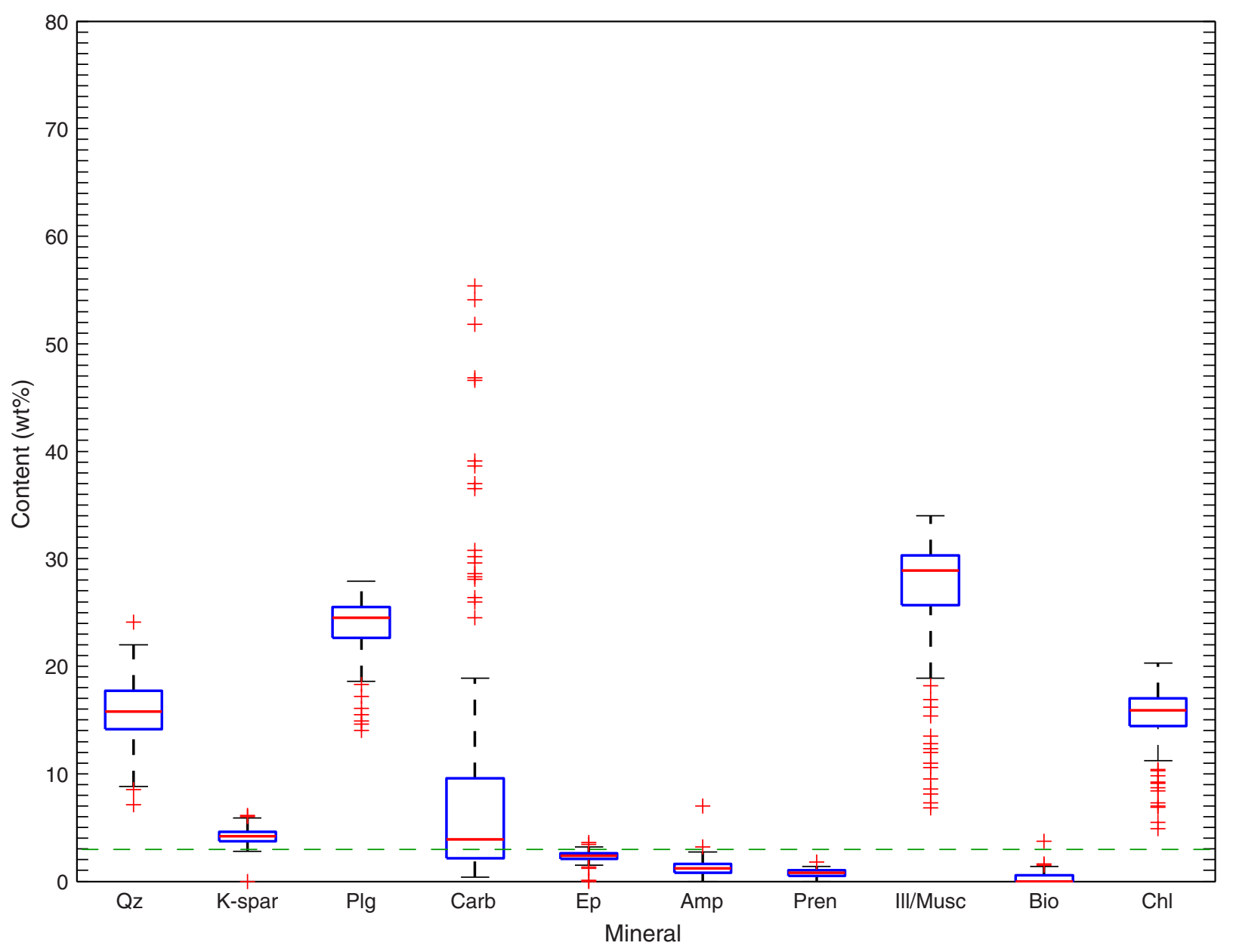


Figure F10. Box plot of the possible primary minerals in Subunit IC, Hole U1352B. See Figure F5 for explanation of figure. See Table T4 for mineral abbreviations.

Hole U1352B, Subunit IC

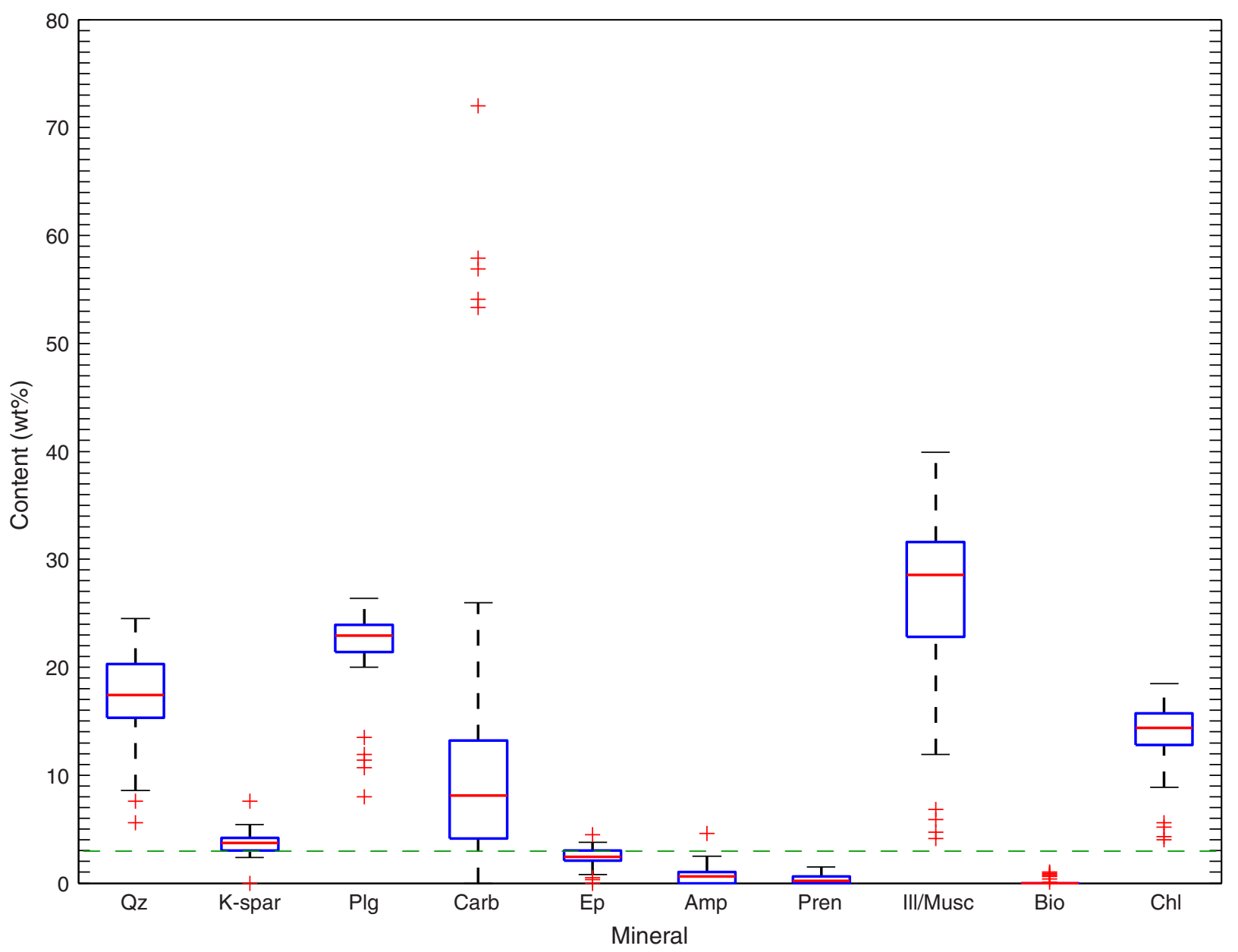


Figure F11. Box plot of the possible primary minerals in Subunit IIA, Hole U1352B. See Figure F5 for explanation of figure. See Table T4 for mineral abbreviations.

Hole U1352B, Subunit IIA

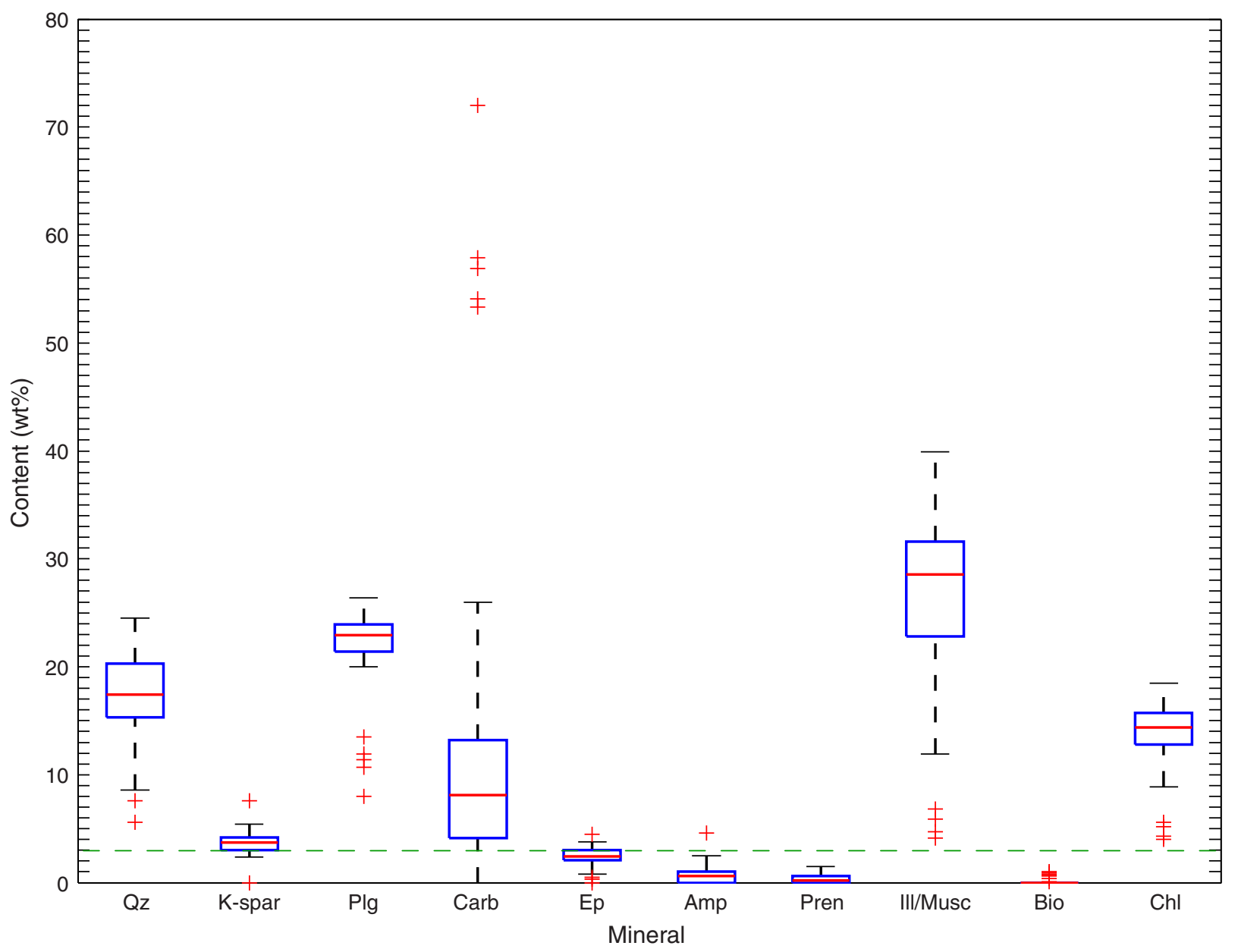


Figure F12. Summary of core recovery, lithology, lithologic units, depositional age, and mineral composition, Hole U1353B. Lithostratigraphic unit boundaries and seismic sequence boundaries are from the "Site U1353" chapter (Expedition 317 Scientists, 2011d). See Figure F4 for explanation of lithology patterns. A. Primary minerals and mineral groups. Msc = muscovite. (Continued on next page.)

A Hole U1353B

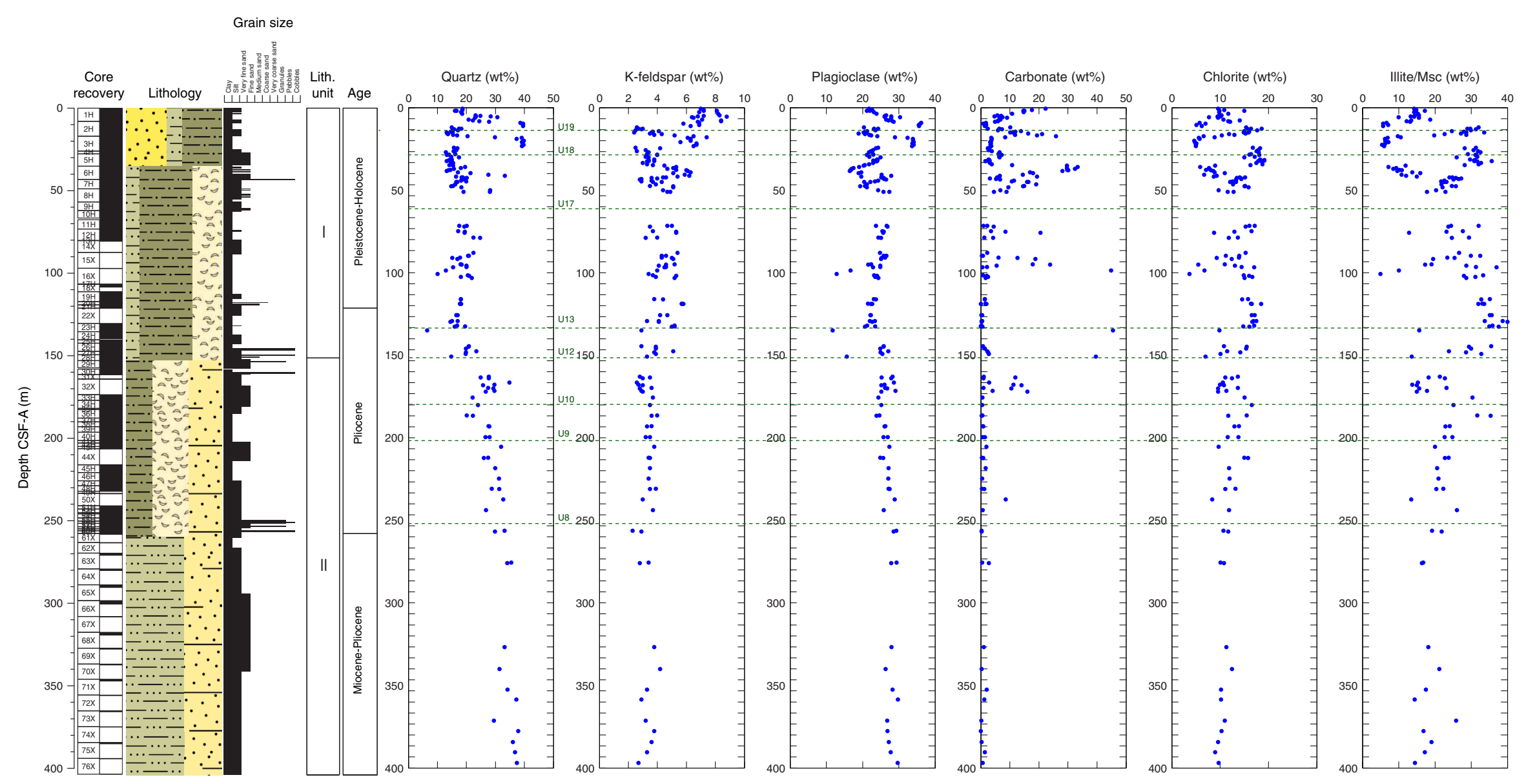


Figure F12 (continued). B. Carbonate minerals.

B Hole U1353B

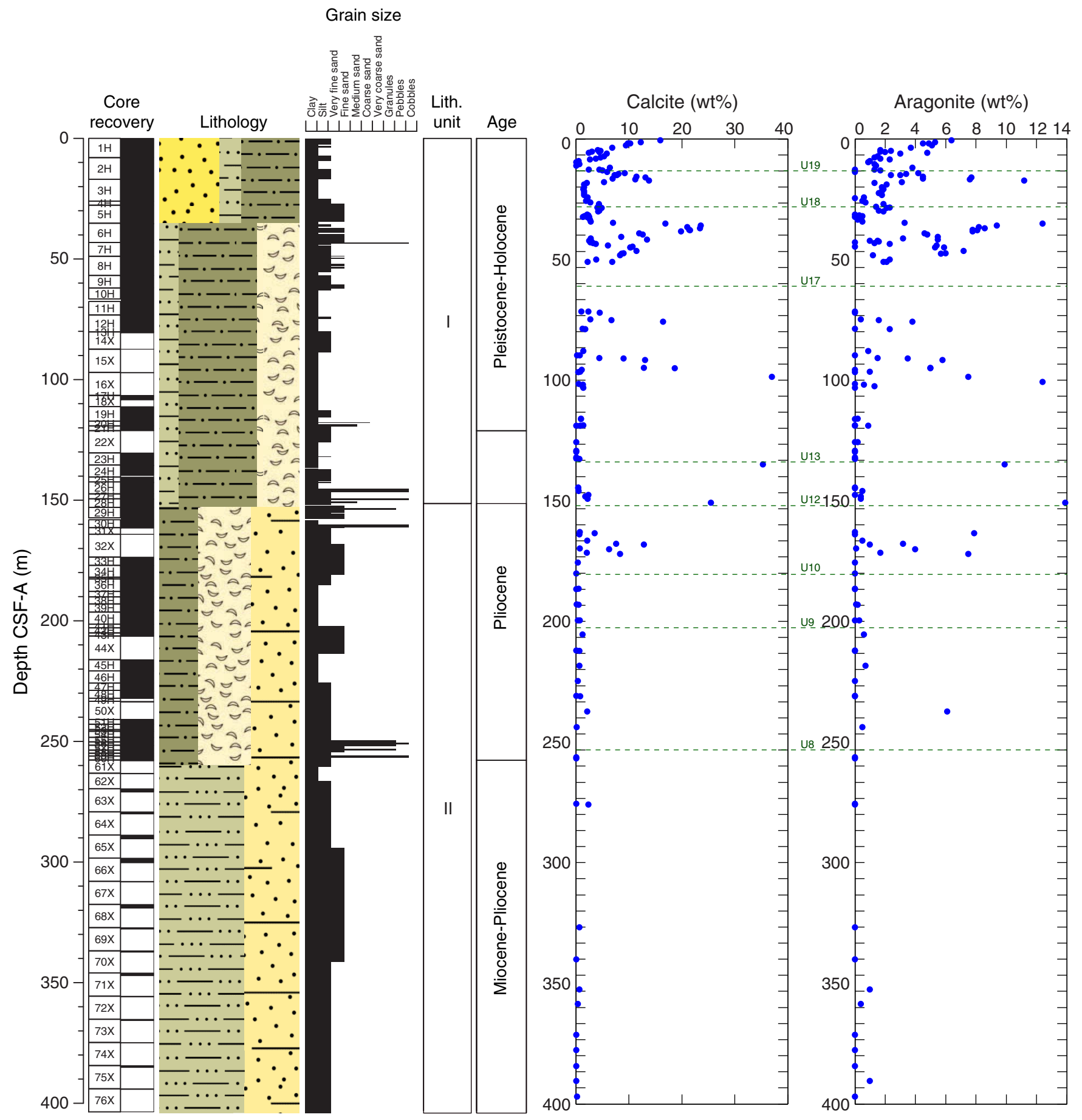


Figure F13. Box plot of the possible primary minerals in Unit I, Hole U1353B. See Figure F5 for explanation of figure. See Table T4 for mineral abbreviations.

Hole U1353B, Unit I

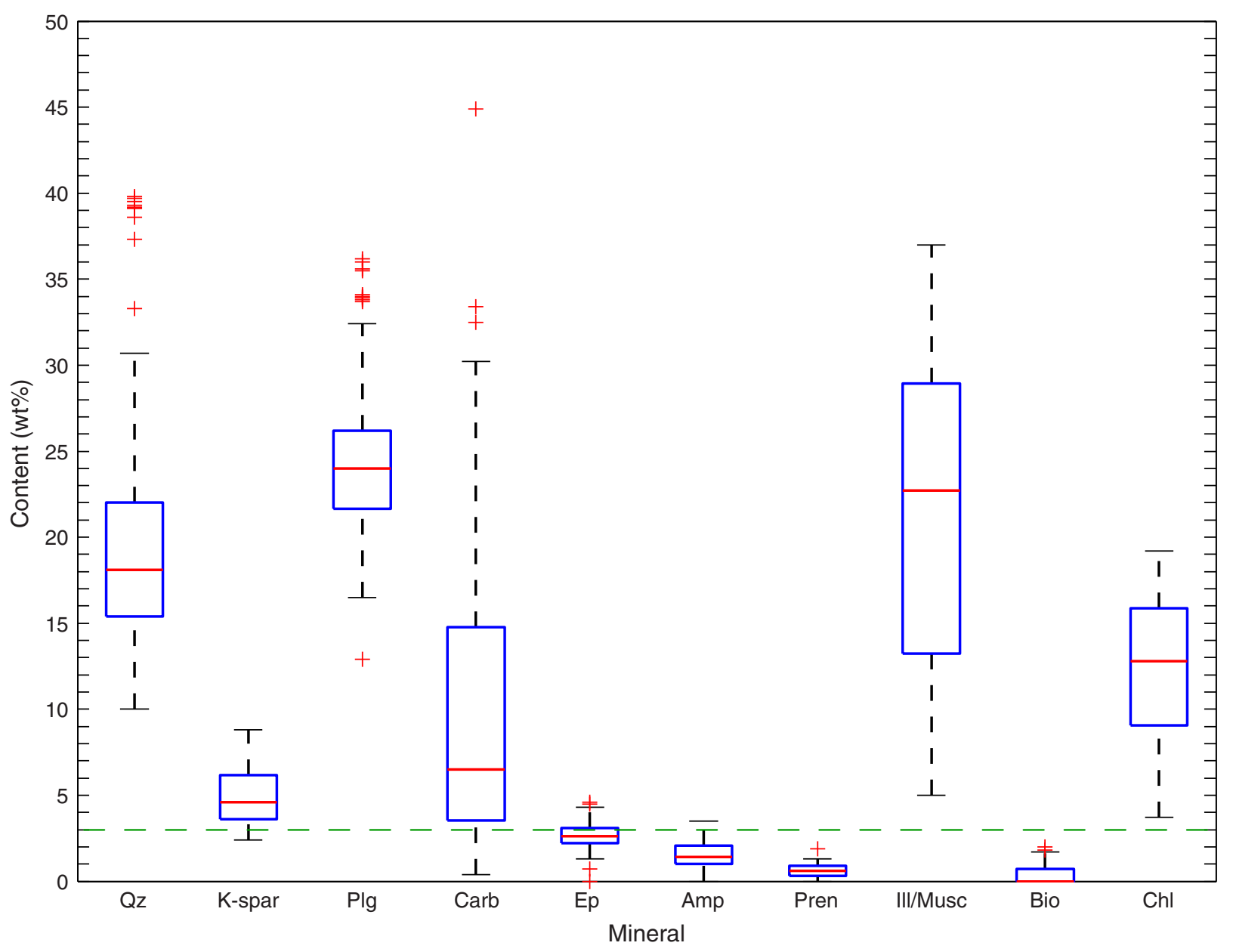


Figure F14. Box plot of the possible primary minerals in Unit II, Hole U1353B. See Figure F5 for explanation of figure. See Table T4 for mineral abbreviations.

Hole U1353B, Unit II

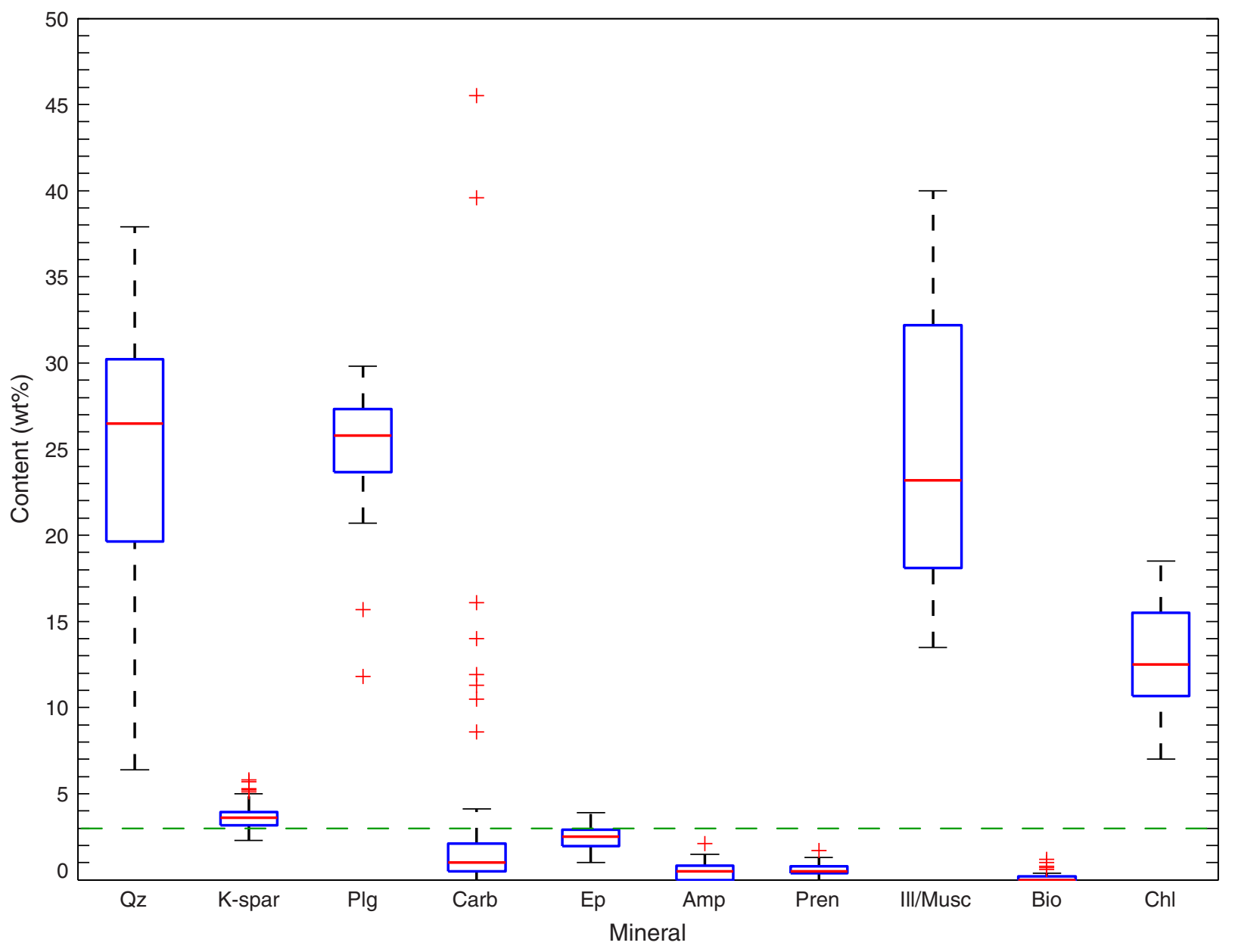


Figure F15. Summary of core recovery, lithology, lithologic units, depositional age, and mineral composition, Hole U1354B. Lithostratigraphic unit boundaries and seismic sequence boundaries are from the "Site U1354" chapter (Expedition 317 Scientists, (2011e). See Figure F4 for explanation of lithology patterns. A. Primary minerals and mineral groups. Msc = muscovite. (Continued on next page.)

A Hole U1354B

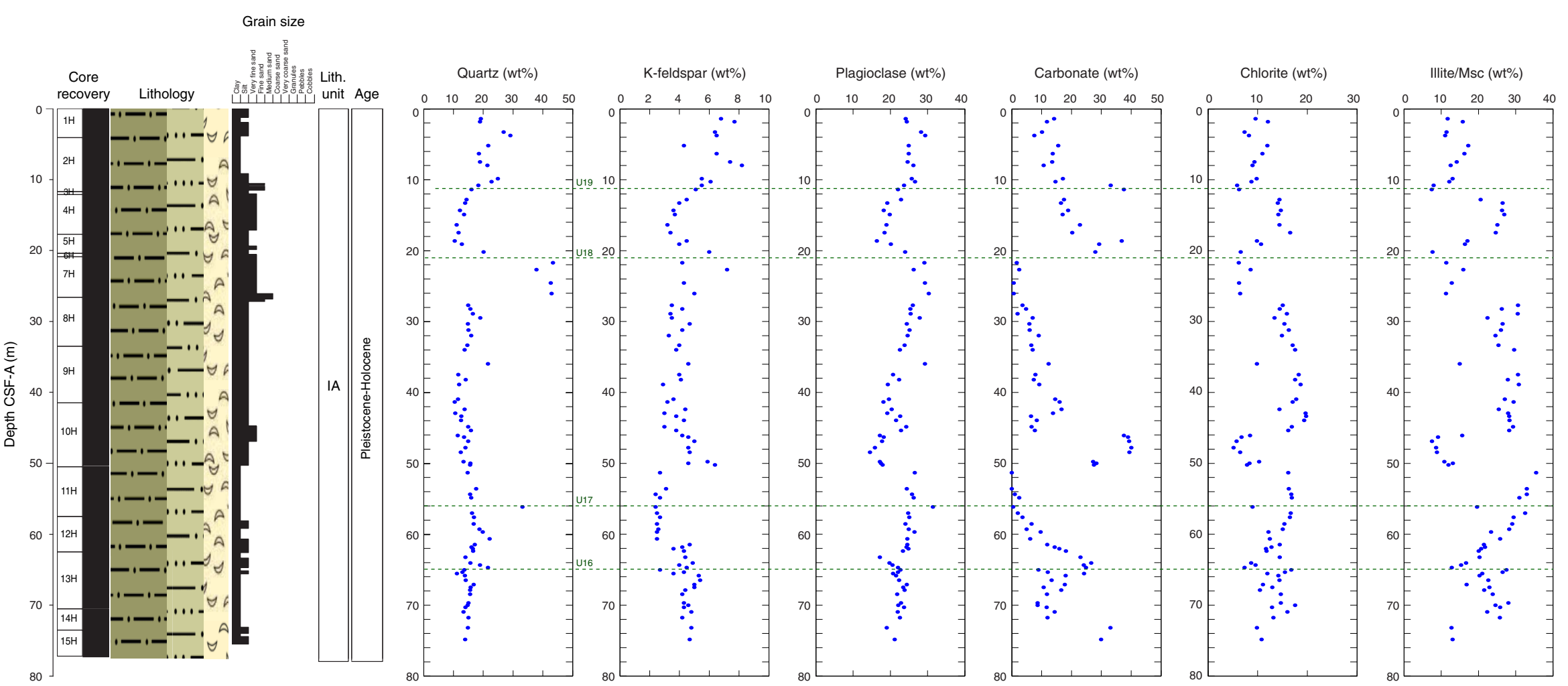


Figure F15 (continued). B. Carbonate minerals.

B Hole U1354B

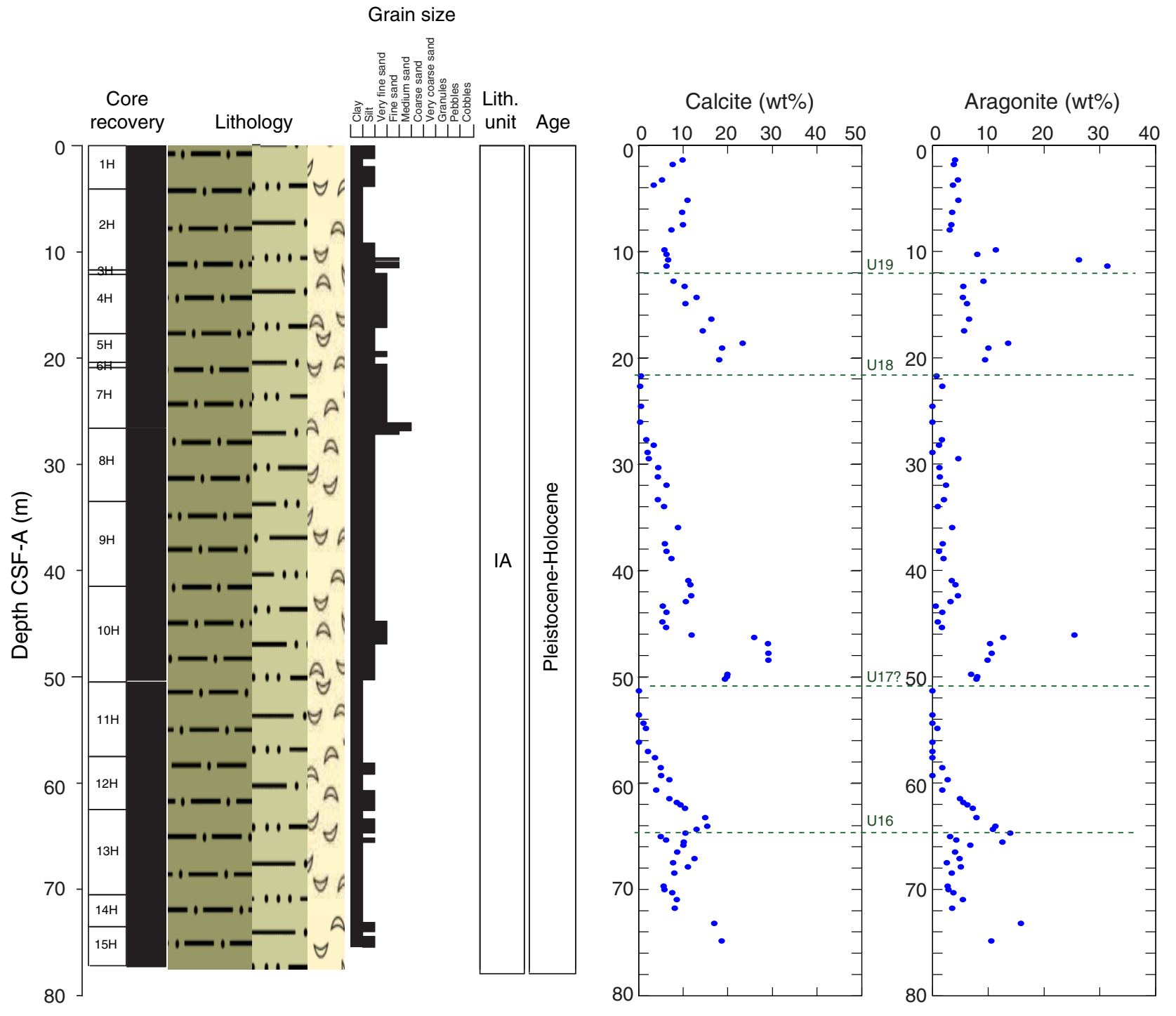


Figure F16. Box plot of the possible primary minerals in Subunit IA, Hole U1354B. See Figure F5 for explanation of figure. See Table T4 for mineral abbreviations.

Hole U1354B, Subunit IA

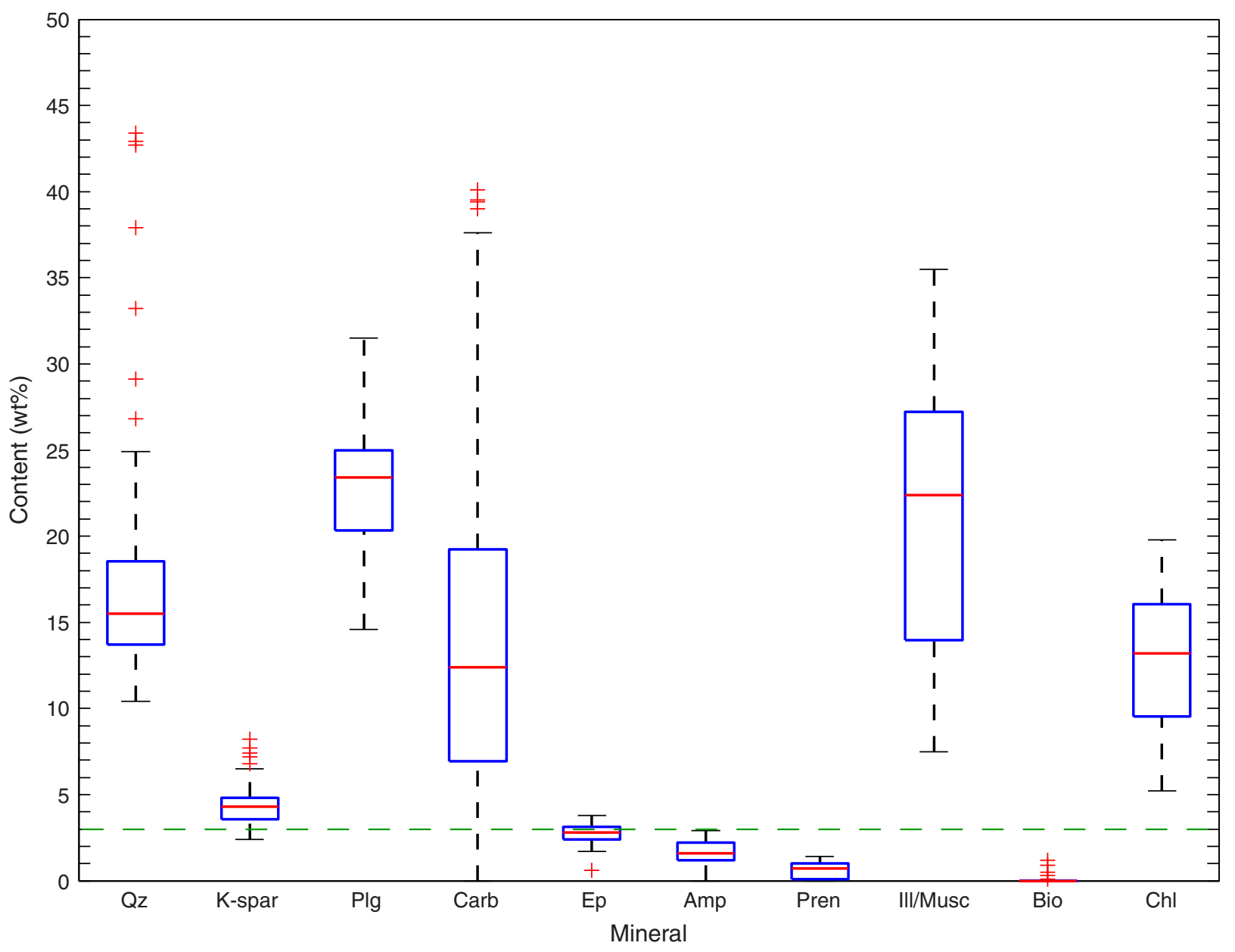


Figure F17. Summary of core recovery, lithology, lithologic units, depositional age, and mineral composition, Hole U1354C. Lithostratigraphic unit boundaries and seismic sequence boundaries are from the "Site U1354" chapter (Expedition 317 Scientists, 2011e). See Figure F4 for explanation of lithology patterns. A. Primary minerals and mineral groups. Msc = muscovite. (Continued on next page.)

A Hole U1354C

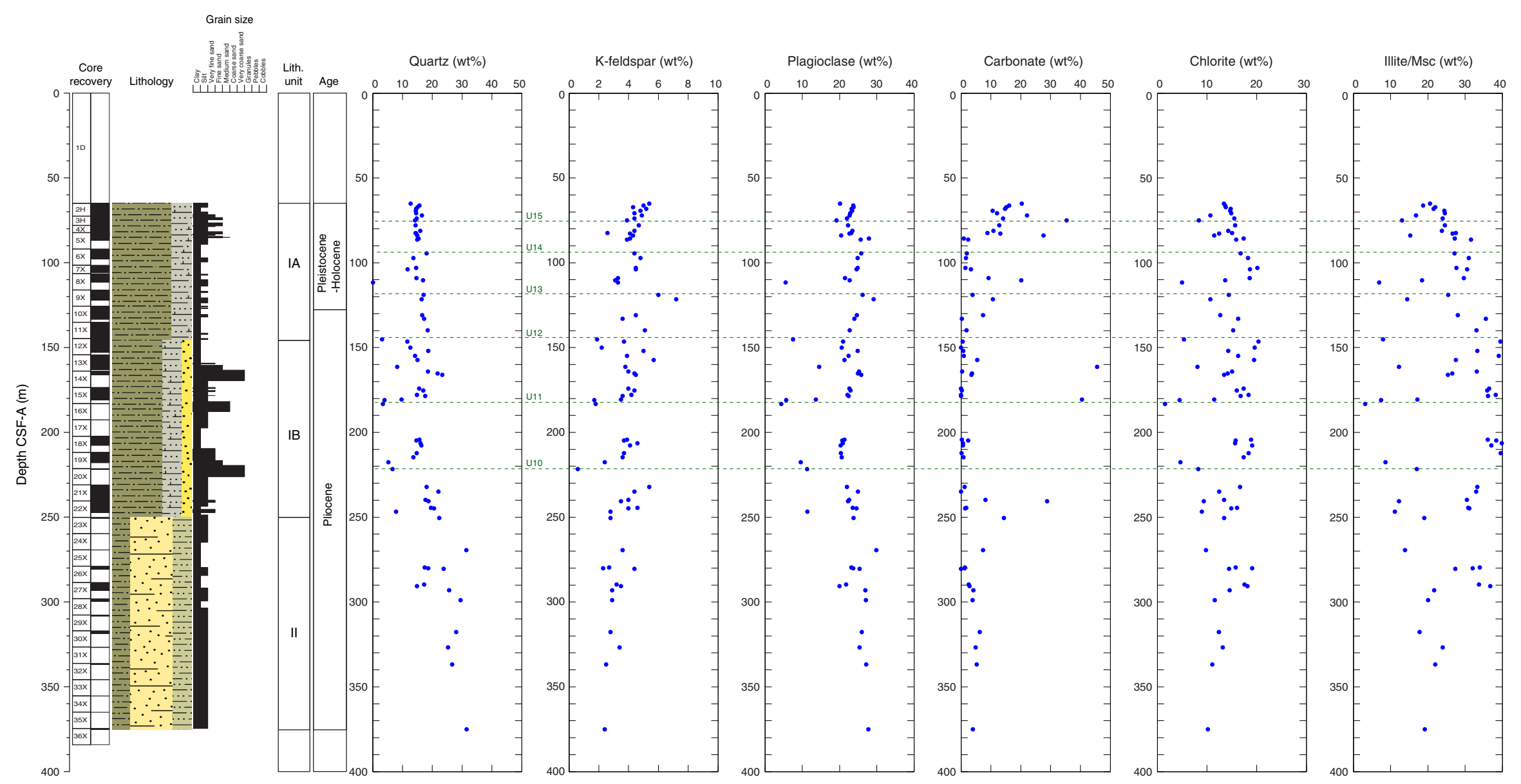


Figure F17 (continued). B. Carbonate minerals.

B Hole U1354C

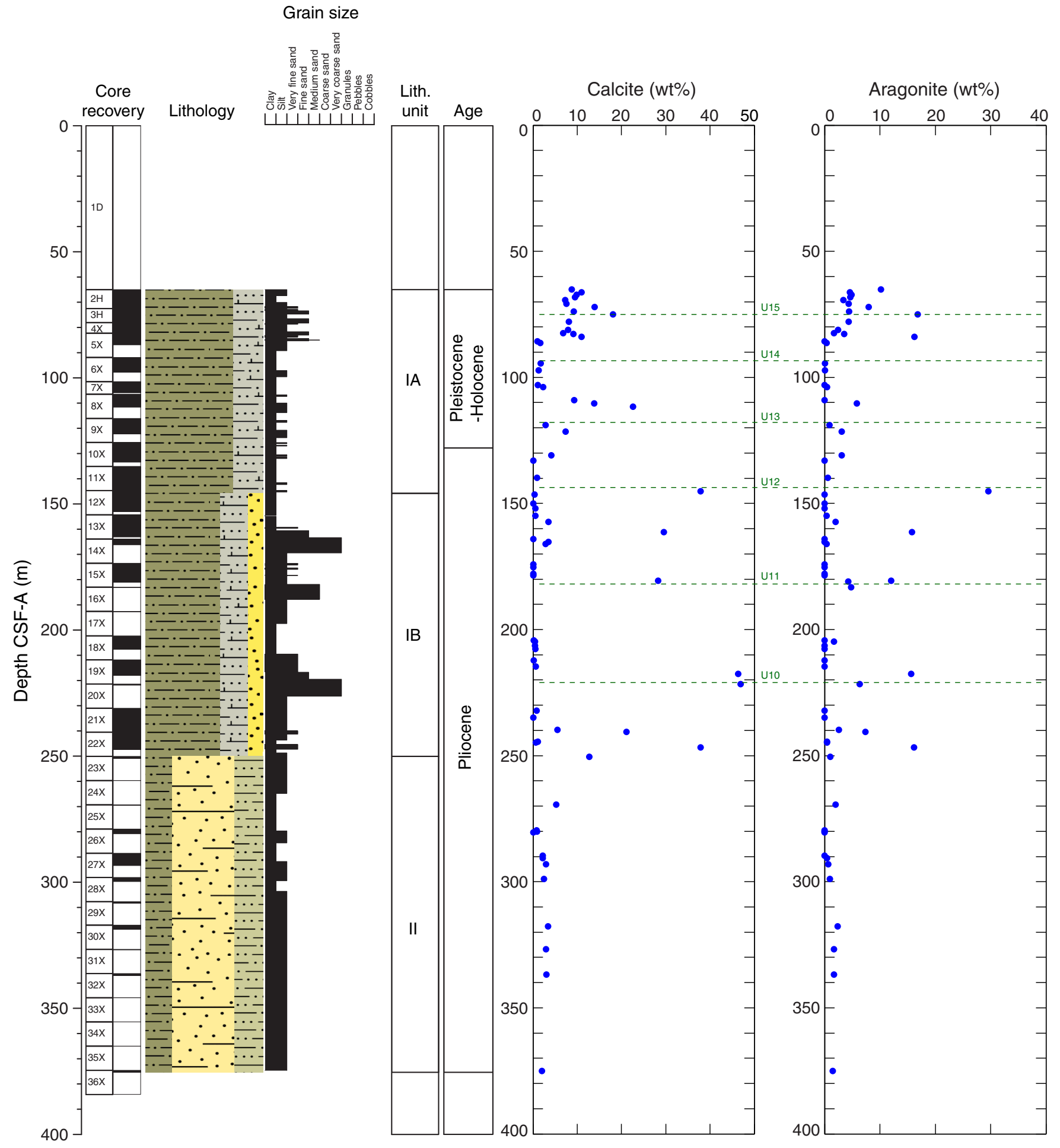


Figure F18. Box plot of the possible primary minerals in Subunit IA, Hole U1354C. See Figure F5 for explanation of figure. See Table T4 for mineral abbreviations.

Hole U1354C, Subunit IA

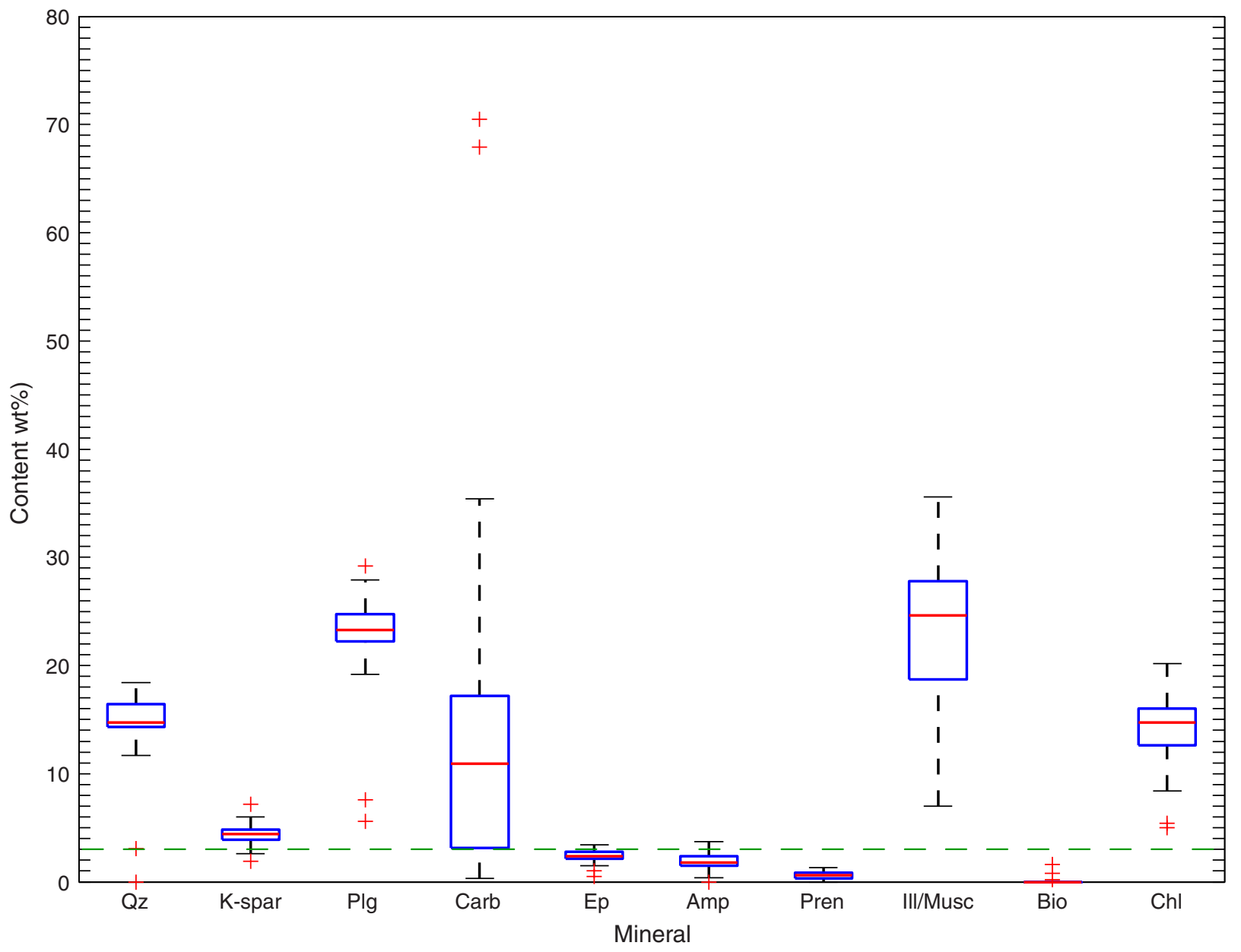


Figure F19. Box plot of the possible primary minerals in Subunit IB, Hole U1354C. See Figure F5 for explanation of figure. See Table T4 for mineral abbreviations.

Hole U1354C, Subunit IB

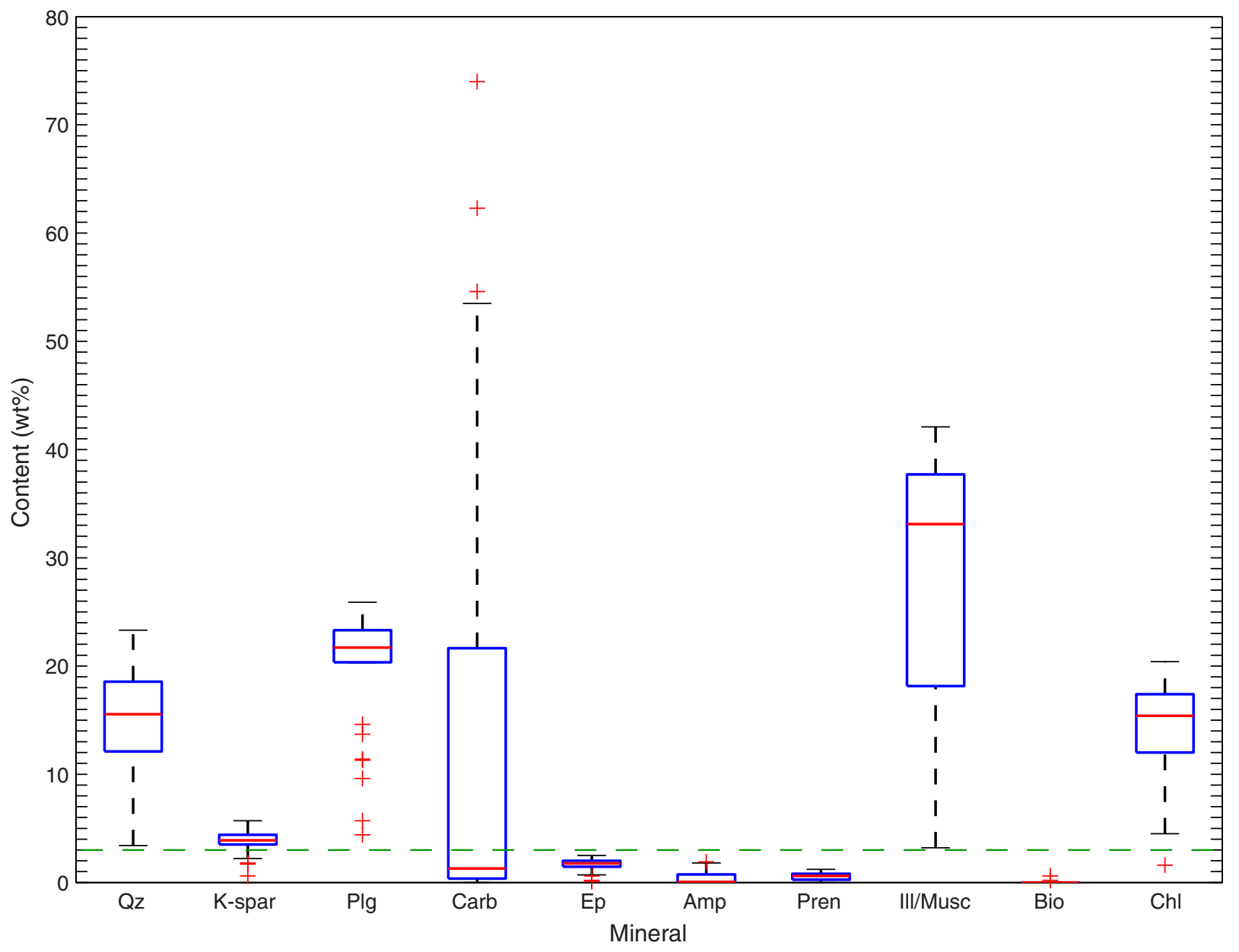


Figure F20. Box plot of the possible primary minerals in Unit II, Hole U1354C. See Figure F5 for explanation of figure. See Table T4 for mineral abbreviations.

Hole U1354C, Unit II

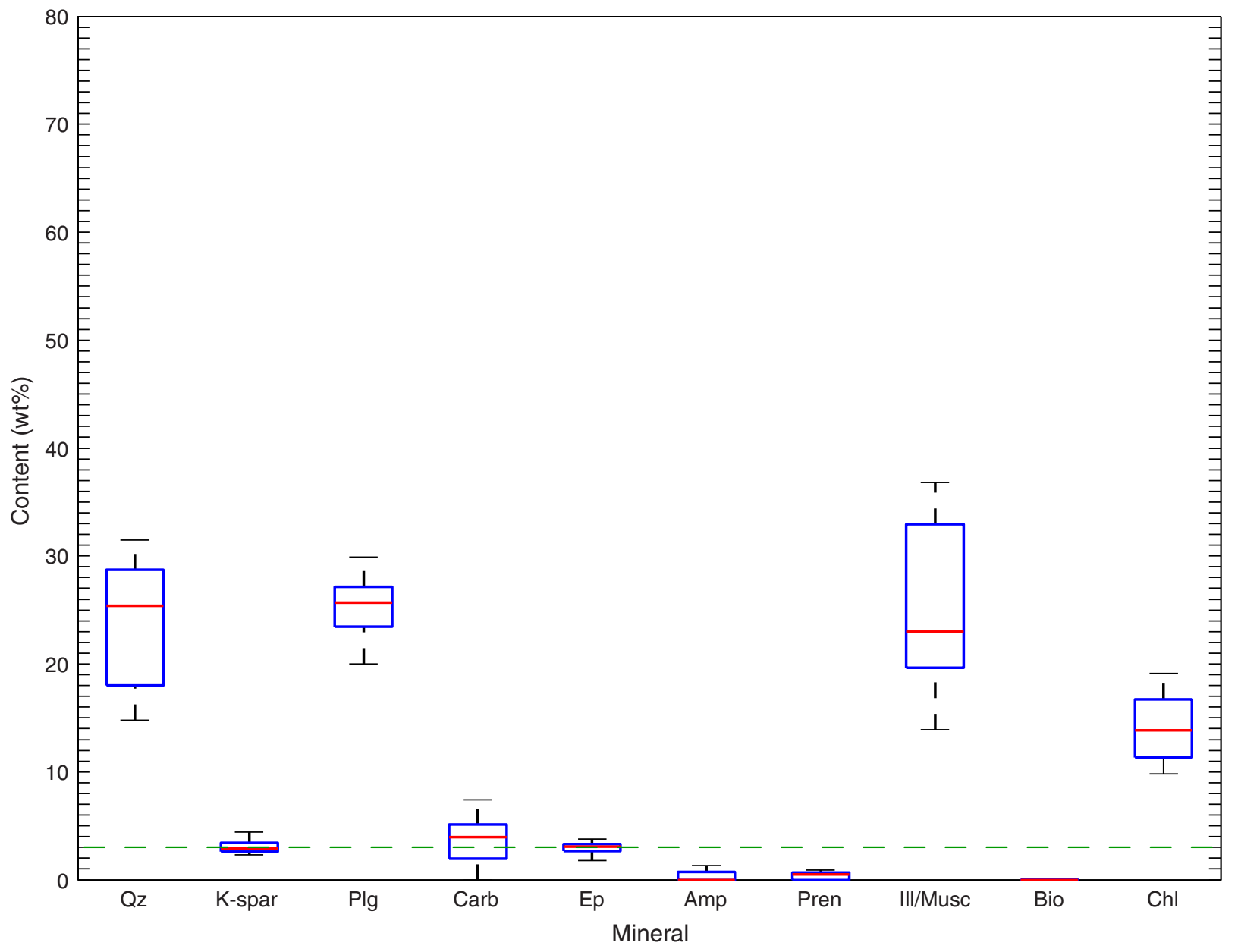


Table T1. Composition of standard samples and their mineralogy after analysis in RockJock, Expedition 317. Sample number is internal lab designation.

\begin{tabular}{|c|c|c|c|c|}
\hline Sample & Mineralogy & $\begin{array}{c}\text { Prepared } \\
\text { concentration } \\
(\%)\end{array}$ & $\begin{array}{l}\text { RockJock } \\
\text { results } \\
(\%)\end{array}$ & $\begin{array}{l}\text { Difference } \\
\quad \text { (wt\%) }\end{array}$ \\
\hline \multirow[t]{4}{*}{12} & Biotite & 20 & 19 & 1 \\
\hline & Quartz & 40 & 42.3 & 2.3 \\
\hline & Albite & 20 & 21 & 1 \\
\hline & Calcite & 20 & 17.9 & 2.1 \\
\hline \multirow[t]{2}{*}{15} & Biotite & 50 & 41.7 & 8.3 \\
\hline & Quartz & 50 & 58 & 8 \\
\hline \multirow[t]{4}{*}{17} & Biotite & 30 & 34 & 4 \\
\hline & Chlorite & 40 & 33 & 7 \\
\hline & Albite & 20 & 21 & 1 \\
\hline & Quartz & 10 & 12.3 & 2.3 \\
\hline \multirow[t]{4}{*}{18} & Biotite & 30 & 31 & 1 \\
\hline & Chlorite & 30 & 25 & 5 \\
\hline & Albite & 30 & 32 & 2 \\
\hline & Quartz & 10 & 11.8 & 1.8 \\
\hline \multirow[t]{4}{*}{19} & Biotite & 40 & 48 & 8 \\
\hline & Muscovite & 10 & 12.6 & 2.6 \\
\hline & Chlorite & 40 & 27.1 & 12.9 \\
\hline & Albite & 10 & 12.6 & 2.6 \\
\hline \multirow[t]{4}{*}{20} & Biotite & 40 & 47 & 7 \\
\hline & Muscovite & 10 & 12 & 2 \\
\hline & Chlorite & 40 & 30 & 10 \\
\hline & Albite & 10 & 11 & 1 \\
\hline \multirow[t]{3}{*}{27} & Muscovite & 40 & 47.6 & 7.6 \\
\hline & Chlorite & 40 & 30.1 & 9.9 \\
\hline & Quartz & 20 & 22.3 & 2.3 \\
\hline \multirow[t]{3}{*}{26} & Muscovite & 40 & 38.8 & 1.2 \\
\hline & Biotite & 40 & 38 & 2 \\
\hline & Quartz & 20 & 23.2 & 3.2 \\
\hline \multirow[t]{4}{*}{ Test 1} & Orthoclase & 2 & 4 & 2 \\
\hline & Labradorite & 30 & 27 & 3 \\
\hline & Quartz & 50 & 53.9 & 3.9 \\
\hline & Chlorite & 18 & 13.2 & 4.8 \\
\hline \multirow[t]{4}{*}{ Test 2} & Orthoclase & 4 & 4.9 & 0.9 \\
\hline & Labradorite & 30 & 29 & 1 \\
\hline & Quartz & 50 & 53.8 & 3.8 \\
\hline & Chlorite & 16 & 12.3 & 3.7 \\
\hline \multirow[t]{4}{*}{ Test 3} & Orthoclase & 8 & 9.6 & 1.6 \\
\hline & Labradorite & 30 & 28.4 & 1.6 \\
\hline & Quartz & 50 & 52.5 & 2.5 \\
\hline & Chlorite & 12 & 9.4 & 2.6 \\
\hline \multirow[t]{4}{*}{ Test 4} & Orthoclase & 10 & 10.2 & 0.2 \\
\hline & Labradorite & 30 & 27.8 & 2.2 \\
\hline & Quartz & 50 & 51 & 1 \\
\hline & Chlorite & 10 & 11 & 1 \\
\hline \multirow[t]{4}{*}{ Test 5} & Orthoclase & 30 & 33.6 & 3.6 \\
\hline & Labradorite & 30 & 26.4 & 3.6 \\
\hline & Quartz & 30 & 28.2 & 1.8 \\
\hline & Chlorite & 10 & 11.7 & 1.7 \\
\hline
\end{tabular}


Table T2. Average accuracy errors for individual minerals, Expedition 317.

\begin{tabular}{|c|c|c|c|}
\hline Mineral & $\begin{array}{l}\text { Average } \\
\text { difference } \\
\text { (wt\%) }\end{array}$ & $\begin{array}{l}\text { Minimum } \\
(\%)\end{array}$ & $\begin{array}{c}\text { Maximum } \\
\text { (\%) }\end{array}$ \\
\hline Quartz & 3.0 & 1.0 & 8.0 \\
\hline Albite & 1.5 & 1.0 & 2.6 \\
\hline Labradorite & 2.3 & 1.0 & 3.6 \\
\hline Orthoclase & 1.7 & 0.2 & 3.6 \\
\hline Biotite & 4.5 & 1.0 & 8.3 \\
\hline Chlorite & 5.9 & 1.0 & 12.9 \\
\hline Muscovite & 3.4 & 1.2 & 7.6 \\
\hline Calcite & 2.1 & 2.1 & 2.1 \\
\hline Average: & 3.0 & & \\
\hline
\end{tabular}

Table T3. Sediment sample splits for method precision testing, Expedition 317.

\begin{tabular}{|c|c|c|c|c|c|}
\hline Mineral & & $\begin{array}{c}\text { Sample } \\
1724811 a \\
\text { (wt\%) }\end{array}$ & $\begin{array}{c}\text { Sample } \\
1724811 \mathrm{~b} \\
(\mathrm{wt} \%)\end{array}$ & $\begin{array}{c}\text { Sample } \\
1724811 \mathrm{c} \\
\text { (wt\%) }\end{array}$ & $\begin{array}{c}\text { Standard } \\
\text { deviation } \\
\text { (\%) }\end{array}$ \\
\hline \multicolumn{6}{|l|}{ Nonclays } \\
\hline Quartz & & 18.3 & 18.5 & 17.1 & 0.8 \\
\hline K-feldspar (orthoclase, microcline, and feldspar) & & 4.2 & 4.3 & 4.7 & 0.3 \\
\hline Plagioclase (albite, oligoclase, and labradorite) & & 24.6 & 24.6 & 25.2 & 0.3 \\
\hline Calcite & & 0.8 & 0.8 & 0.8 & 0.0 \\
\hline Aragonite & & 0.4 & 0.5 & 0.3 & 0.1 \\
\hline Dolomite & & 0.2 & 0.1 & 0.2 & 0.0 \\
\hline Halite & & 0.3 & 0.3 & 0.5 & 0.1 \\
\hline Pyrite & & 0.5 & 0.6 & 0.6 & 0.1 \\
\hline Epidote & & 1.2 & 1.0 & 1.1 & 0.1 \\
\hline Hornblende amphibole & & 0.0 & 0.0 & 0.0 & 0.0 \\
\hline Prehnite & & 0.1 & 0.3 & 0.3 & 0.1 \\
\hline \multicolumn{6}{|l|}{ Clays } \\
\hline Kaolinite (disordered, ordered, and dry branch) & & 0.2 & 0.0 & 0.5 & 0.2 \\
\hline Smectite (Na- and Ca-Kinney montmorillonite) & & 0.0 & 0.0 & 0.0 & 0.0 \\
\hline Illite $(1 \mathrm{Md}, 1 \mathrm{M}, 2 \mathrm{M})$ & & 3.4 & 4.2 & 5.7 & 1.2 \\
\hline Muscovite (2M1) & & 26.8 & 26.2 & 25.8 & 0.5 \\
\hline Glauconite & & 5.5 & 5.2 & 4.3 & 0.6 \\
\hline Biotite $(1 \mathrm{M})$ & & 0.0 & 0.0 & 0.0 & 0.0 \\
\hline Phlogopite (2M1) & & 1.1 & 0.4 & 0.0 & 0.6 \\
\hline \multirow[t]{2}{*}{ Chlorite (Cca, CMM, Fe rich, and Mg rich) } & & 12.4 & 12.9 & 12.7 & 0.3 \\
\hline & Total: & 100.0 & 100.0 & 100.0 & \\
\hline
\end{tabular}

Full pattern degree of fit: Sample $1724811 \mathrm{a}=0.0856$, Sample $1724811 \mathrm{~b}=0.0944$, Sample $1724811 \mathrm{c}=0.0845$. 
Table T4. List of minerals used in the diffraction pattern analysis in RockJock, Expedition 317.

\begin{tabular}{|c|c|c|c|c|c|}
\hline Mineral & Abbreviation & $\begin{array}{c}\text { Average } \\
\text { (wt\%) }\end{array}$ & $\begin{array}{l}\text { Standard } \\
\text { deviation } \\
\text { (wt\%) }\end{array}$ & $\underset{(w t \%)}{\text { Minimum }}$ & $\begin{array}{c}\text { Maximum } \\
(\mathrm{wt} \%)\end{array}$ \\
\hline \multicolumn{6}{|l|}{ Nonclays } \\
\hline Quartz & Qz & 18.8 & 6.4 & 0.0 & 43.4 \\
\hline K-feldspar (orthoclase microcline and feldspar) & K-spar & 4.1 & 1.1 & 0.0 & 8.8 \\
\hline Plagioclase (albite, oligoclase, and labradorite) & $\mathrm{Plg}$ & 23.9 & 3.8 & 4.4 & 36.2 \\
\hline Calcite & Carb, Carbonates & 6.9 & 9.8 & 0.0 & 76.2 \\
\hline Aragonite & Carb, Carbonates & 2.5 & 4.4 & 0.0 & 47.8 \\
\hline Dolomite & Carb, Carbonates & 0.4 & 0.4 & 0.0 & 4.4 \\
\hline Halite & $\mathrm{Hal}$ & 0.2 & 0.2 & 0.0 & 3.0 \\
\hline Pyrite & Py & 0.5 & 0.3 & 0.0 & 2.4 \\
\hline Epidote & Ep & 2.4 & 0.7 & 0.0 & 4.6 \\
\hline Hornblende amphibole & Amp & 1.0 & 0.9 & 0.0 & 7.0 \\
\hline Prenhite & Pren & 0.6 & 0.4 & 0.0 & 1.9 \\
\hline Hematite $^{*}$ & Hem & 0.0 & 0.0 & 0.0 & 0.3 \\
\hline \multicolumn{6}{|l|}{ Clays } \\
\hline Kaolinite (disordered, ordered, and dry branch) & Kao & 0.2 & 0.4 & 0.0 & 4.0 \\
\hline Smectite (Na- and Ca-Kinney montmorillonite) & Smec & 0.2 & 0.8 & 0.0 & 9.2 \\
\hline Illite $(1 \mathrm{Md}, 1 \mathrm{M}, 2 \mathrm{M})$ & III/Musc, Illite/Musc & 1.8 & 2.7 & 0.0 & 15.8 \\
\hline Muscovite (2M1) & III/Musc, Illite/Musc & 22.3 & 7.2 & 2.4 & 42.1 \\
\hline Glauconite $^{\dagger}$ & Bio & 1.7 & 1.6 & 0.0 & 5.8 \\
\hline Biotite $(1 \mathrm{M})$ & Bio & 0.0 & 0.2 & 0.0 & 1.9 \\
\hline Phlogopite (2M1) & Bio & 0.3 & 0.4 & 0.0 & 3.7 \\
\hline Chlorite (Cca, CMM, Fe rich, and Mg rich) & $\mathrm{Chl}$ & 13.5 & 3.6 & 1.6 & 21.7 \\
\hline
\end{tabular}

* = only in Site U1352 samples, $\dagger=$ only in Site U1351 samples. Full pattern degree of fit: average $=0.097$, standard deviation $=0.011$, minimum $=0.071$, maximum $=0.200$. Statistics apply to all samples analyzed from four sites. Full pattern degree of fit parameter between the calculated and measured pattern for all samples are included, and values $<0.1$ are preferable (Eberl, 2003). Abbreviations of minerals used in the report are noted. 
Content (wt\%)

\begin{tabular}{|c|c|c|c|c|c|c|c|c|c|c|c|c|c|c|c|c|c|c|c|c|c|c|c|c|}
\hline \multirow{3}{*}{$\begin{array}{l}\text { Core, section, } \\
\text { interval (cm) }\end{array}$} & & & \multirow[b]{3}{*}{ Text ID } & \multirow{3}{*}{\multicolumn{3}{|c|}{ 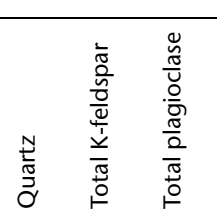 }} & \multirow{3}{*}{$\frac{\stackrel{5}{v}}{\frac{v}{v}}$} & & \multirow{3}{*}{ 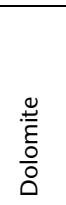 } & \multirow{3}{*}{$\frac{\stackrel{\mathscr{V}}{\bar{T}}}{\frac{\pi}{I}}$} & & & & \multirow{3}{*}{$\begin{array}{l}\frac{0}{\circ} \\
\frac{0}{\bar{\Xi}} \\
\frac{\hat{\sigma}}{\xi} \\
\frac{\xi}{4}\end{array}$} & \multirow{3}{*}{ 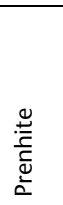 } & & & & & & & & & \\
\hline & Deptr & & & & & & & \multirow{2}{*}{ 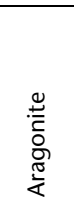 } & & & \multirow{2}{*}{ 䒿 } & \multirow{2}{*}{ 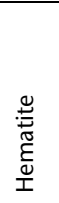 } & \multirow{2}{*}{$\begin{array}{l}\frac{0}{0} \\
\frac{0}{0} \\
\frac{0}{4}\end{array}$} & & & \multirow{2}{*}{ 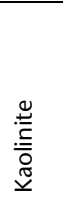 } & \multirow{2}{*}{ 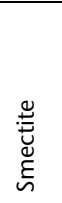 } & \multirow{2}{*}{$\stackrel{\stackrel{\Xi}{\equiv}}{=}$} & \multirow{2}{*}{ 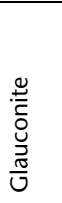 } & & 产 & $\stackrel{\Perp}{=}$ & 苛 & \\
\hline & Top & Bottom & & & & & & & & & & & & & & & & & & $\frac{0}{0}$ & $\frac{b}{a}$ & $\overline{\bar{U}}$ & $\sum^{2}$ & of fit \\
\hline 317-U1351B- & & & & & & & & & & & & & & & & & & & & & & & & \\
\hline $1 \mathrm{H}-1,78-79$ & 0.78 & 0.79 & CYL1703321 & 17.6 & 6.2 & 24.3 & 17.0 & 7.2 & 0.3 & 0.6 & 0.6 & & 2.5 & 2.0 & 0.5 & 0.9 & 0.0 & 0.0 & 2.2 & 0.0 & 0.2 & 8.0 & 9.9 & 0.088 \\
\hline $1 \mathrm{H}-1,107-109$ & 1.07 & 1.09 & CYL1703381 & 17.3 & 7.3 & 23.7 & 15.2 & 5.6 & 0.3 & 0.6 & 0.6 & & 2.2 & 2.1 & 0.2 & 0.6 & 0.0 & 0.0 & 1.9 & 0.0 & 0.8 & 11.0 & 10.8 & 0.083 \\
\hline $1 \mathrm{H}-2,66-68$ & 2.16 & 2.18 & CYL1413142 & 24.1 & 7.2 & 27.9 & 6.5 & 4.0 & 0.2 & 0.5 & 0.7 & & 2.3 & 1.9 & 0.6 & 1.1 & 0.5 & 0.0 & 2.7 & 0.5 & 0.4 & 7.9 & 11.0 & 0.082 \\
\hline $1 \mathrm{H}-2,125-127$ & 2.75 & 2.77 & CYL1413152 & 17.8 & 5.5 & 22.0 & 7.4 & 22.5 & 0.3 & 0.3 & 0.9 & & 1.9 & 1.1 & 0.7 & 0.3 & 0.0 & 0.0 & 1.5 & 0.2 & 0.5 & 6.6 & 10.7 & 0.083 \\
\hline $1 \mathrm{H}-2,143-147$ & 2.93 & 2.95 & WDGE1512012 & 16.2 & 5.0 & 20.6 & 8.4 & 24.4 & 0.3 & 0.2 & 0.3 & & 1.8 & 2.5 & 0.8 & 0.8 & 0.0 & 0.0 & 0.0 & 0.0 & 0.0 & 8.5 & 10.1 & 0.096 \\
\hline $1 \mathrm{H}-3,25-27$ & 3.25 & 3.27 & CYL1413162 & 16.7 & 5.3 & 24.3 & 3.2 & 3.7 & 0.4 & 0.5 & 0.3 & & 2.6 & 0.9 & 0.2 & 0.3 & 0.0 & 1.7 & 3.3 & 0.0 & 0.0 & 14.5 & 22.2 & 0.094 \\
\hline $1 \mathrm{H}-3,122-124$ & 4.22 & 4.24 & CYL1413172 & 19.4 & 4.2 & 27.1 & 4.1 & 5.8 & 0.5 & 0.3 & 0.6 & & 3.1 & 1.3 & 0.6 & 0.0 & 0.0 & 0.0 & 2.2 & 0.0 & 0.0 & 12.2 & 18.7 & 0.091 \\
\hline $1 \mathrm{H}-5,67-69$ & 6.67 & 6.69 & CYL1413182 & 13.3 & 3.8 & 22.1 & 1.4 & 0.7 & 0.4 & 0.3 & 0.6 & & 2.2 & 1.0 & 0.5 & 0.0 & 0.0 & 0.0 & 3.4 & 0.0 & 0.3 & 17.5 & 32.5 & 0.095 \\
\hline $1 \mathrm{H}-6,26-28$ & 7.26 & 7.28 & CYL1413192 & 13.5 & 4.5 & 23.3 & 2.3 & 1.3 & 0.5 & 0.3 & 0.5 & & 2.2 & 0.6 & 0.4 & 0.0 & 0.0 & 0.0 & 2.9 & 0.0 & 0.0 & 17.7 & 30.1 & 0.109 \\
\hline $2 \mathrm{H}-1,71-73$ & 8.51 & 8.53 & CUBE1705681 & 14.2 & 3.1 & 23.6 & 0.0 & 0.0 & 0.0 & 0.0 & 0.7 & & 2.7 & 0.0 & 0.0 & 0.0 & 0.0 & 3.5 & & 0.0 & 0.0 & 19.4 & 32.9 & 0.107 \\
\hline $2 \mathrm{H}-2,89-91$ & 10.19 & 10.21 & CYL1413202 & 13.7 & 3.4 & 22.4 & 3.6 & 1.6 & 0.4 & 0.3 & 0.6 & & 2.6 & 0.6 & 0.3 & 0.0 & 0.0 & 0.0 & 3.1 & 0.0 & 0.5 & 16.8 & 30.3 & 0.108 \\
\hline $2 \mathrm{H}-3,25-27$ & 11.05 & 11.07 & CYL1413212 & 14.8 & 4.3 & 22.6 & 5.3 & 3.0 & 0.4 & 0.2 & 0.5 & & 2.8 & 0.9 & 0.4 & 0.0 & 0.0 & 0.0 & 3.2 & 0.0 & 0.0 & 15.5 & 26.1 & 0.109 \\
\hline $2 \mathrm{H}-3,120-122$ & 12.00 & 12.02 & CYL1413222 & 16.6 & 4.5 & 24.4 & 9.5 & 9.1 & 0.3 & 0.2 & 0.4 & & 2.6 & 1.8 & 0.8 & 0.0 & 0.0 & 0.0 & 0.0 & 0.0 & 0.6 & 13.2 & 16.0 & 0.096 \\
\hline $2 \mathrm{H}-4$ & 13.31 & 13.32 & CYL1706461 & 19.0 & 7.9 & 26.2 & 13.7 & 4.8 & 0.1 & 0.2 & 0.7 & & 2.6 & 1.8 & 0.2 & 0.7 & 0.0 & 0.0 & 2.6 & 0.4 & 0.0 & 8.4 & 10.8 & 0.094 \\
\hline $2 \mathrm{H}-5,13-15$ & 13.93 & 13.95 & CYL1413232 & 19.2 & 6.7 & 24.7 & 11.6 & 3.3 & 0.2 & 0.3 & 0.7 & & 2.9 & 2.7 & 1.0 & 1.1 & 0.0 & 1.6 & 0.0 & 0.0 & 1.4 & 11.4 & 11.6 & 0.080 \\
\hline $2 \mathrm{H}-5,139-141$ & 15.19 & 15.21 & CYL1413242 & 18.7 & 7.3 & 22.9 & 8.9 & 15.4 & 0.4 & 0.4 & 0.7 & & 1.5 & 1.1 & 0.0 & 0.0 & 0.0 & 0.0 & 0.0 & 0.0 & 0.0 & 12.3 & 10.4 & 0.088 \\
\hline $2 \mathrm{H}-6,53-57$ & 15.83 & 15.85 & WDGE1512022 & 7.5 & 4.3 & 13.6 & 12.4 & 36.5 & 0.3 & 0.1 & 0.6 & & 1.0 & 1.9 & 0.9 & 0.6 & 0.0 & 0.0 & 0.0 & 0.0 & 0.0 & 10.2 & 10.2 & 0.127 \\
\hline $2 \mathrm{H}-6,73-75$ & 16.03 & 16.05 & CYL1413252 & 18.4 & 4.7 & 25.8 & 2.0 & 0.5 & 0.3 & 0.4 & 0.5 & & 2.9 & 1.7 & 1.0 & 0.0 & 0.0 & 0.1 & 0.0 & 0.0 & 0.6 & 17.0 & 24.0 & 0.098 \\
\hline $3 \mathrm{H}-1,52-54$ & 17.22 & 17.24 & CYL1413262 & 14.0 & 3.6 & 23.9 & 1.6 & 2.5 & 0.5 & 0.2 & 0.4 & & 2.4 & 0.6 & 0.8 & 0.0 & 0.0 & 0.0 & 3.8 & 0.0 & 0.0 & 17.6 & 28.2 & 0.101 \\
\hline $3 \mathrm{H}-1,110-112$ & 17.80 & 17.82 & CYL1413272 & 19.9 & 5.4 & 28.6 & 5.1 & 2.7 & 0.3 & 0.2 & 0.6 & & 2.9 & 1.6 & 0.5 & 0.0 & 0.0 & 0.0 & 2.9 & 0.0 & 0.2 & 11.2 & 17.7 & 0.091 \\
\hline $3 \mathrm{H}-2,40-42$ & 18.60 & 18.62 & CYL1648262 & 14.5 & 3.4 & 22.7 & 1.0 & 0.3 & 0.5 & 0.2 & 0.2 & & 3.2 & 1.3 & 0.6 & 0.0 & 0.0 & 0.0 & 0.0 & 0.0 & 1.0 & 18.9 & 32.2 & 0.108 \\
\hline $3 \mathrm{H}-2$ & 19.22 & 19.22 & CYL1707771 & 14.7 & 4.4 & 23.5 & 0.9 & 0.0 & 0.9 & 0.5 & 0.6 & & 3.2 & 1.4 & 0.2 & 0.0 & 0.0 & 0.0 & 2.0 & 0.0 & 0.0 & 17.7 & 29.9 & 0.109 \\
\hline $3 \mathrm{H}-3,47-49$ & 20.17 & 20.19 & CYL1648272 & 15.7 & 5.0 & 26.0 & 1.2 & 1.2 & 0.2 & 0.2 & 0.7 & & 2.9 & 3.6 & 0.7 & 0.0 & 0.0 & 0.1 & 0.0 & 0.0 & 1.5 & 15.9 & 25.0 & 0.103 \\
\hline $3 \mathrm{H}-3,145-147$ & 21.15 & 21.17 & CUBE1707191 & 15.4 & 4.7 & 25.0 & 0.9 & 0.0 & 0.4 & 0.2 & 0.6 & & 2.4 & 1.6 & 1.0 & 0.0 & 0.0 & 4.0 & & 0.0 & 1.0 & 17.6 & 25.3 & 0.101 \\
\hline $3 \mathrm{H}-4,7-9$ & 21.27 & 21.29 & CYL1413282 & 19.9 & 5.8 & 30.2 & 3.1 & 1.5 & 0.3 & 0.2 & 0.6 & & 3.2 & 2.3 & 1.0 & 0.3 & 0.0 & 0.0 & 2.0 & 0.0 & 1.2 & 12.0 & 16.5 & 0.090 \\
\hline $3 \mathrm{H}-4,81-83$ & 22.01 & 22.03 & CYL1413292 & 16.7 & 4.0 & 27.3 & 1.2 & 0.1 & 0.4 & 0.1 & 0.3 & & 2.9 & 1.4 & 0.7 & 0.0 & 0.0 & 0.0 & 2.4 & 0.0 & 0.0 & 16.1 & 26.5 & 0.096 \\
\hline $4 \mathrm{H}-1,40-42$ & 22.50 & 22.52 & CYL1709991 & 15.9 & 4.9 & 28.1 & 1.7 & 0.4 & 0.3 & 0.2 & 0.5 & & 2.5 & 0.5 & 0.3 & 0.0 & 0.0 & 0.0 & 2.9 & 0.0 & 0.0 & 14.1 & 27.7 & 0.099 \\
\hline $4 \mathrm{H}-1,50-52$ & 22.60 & 22.62 & CUBE1709101 & 17.0 & 3.4 & 29.0 & 0.0 & 0.0 & 0.0 & 0.0 & 0.5 & & 3.9 & 0.0 & 0.0 & 0.0 & 0.0 & 1.5 & & 0.0 & 0.0 & 17.6 & 27.2 & 0.102 \\
\hline $4 \mathrm{H}-1,139-142$ & 23.49 & 23.51 & WDGE1512032 & 18.2 & 5.4 & 27.1 & 9.0 & 23.3 & 0.4 & 0.0 & 0.5 & & 1.6 & 1.6 & 0.0 & 0.0 & 0.0 & 0.0 & 0.0 & 0.0 & 0.0 & 5.6 & 7.3 & 0.095 \\
\hline $4 \mathrm{H}-2,40-42$ & 24.00 & 24.02 & CYL1413302 & 12.2 & 4.8 & 20.7 & 16.4 & 7.9 & 0.3 & 0.1 & 0.9 & & 2.6 & 2.3 & 0.5 & 0.8 & 0.0 & 0.0 & 2.7 & 0.0 & 0.4 & 12.2 & 15.1 & 0.086 \\
\hline $4 \mathrm{H}-3,50-52$ & 25.60 & 25.62 & CYL1413312 & 10.7 & 3.6 & 17.3 & 23.9 & 12.2 & 0.3 & 0.3 & 0.5 & & 2.4 & 1.2 & 0.6 & 0.0 & 0.0 & 0.0 & 0.9 & 0.0 & 0.0 & 10.1 & 16.0 & 0.111 \\
\hline $4 \mathrm{H}-4,101-102$ & 27.61 & 27.62 & CYL1710841 & 18.9 & 5.5 & 23.8 & 19.2 & 12.5 & 0.2 & 0.5 & 0.7 & & 1.8 & 2.4 & 0.2 & 0.0 & 0.0 & 0.0 & 0.0 & 0.0 & 0.0 & 8.3 & 6.0 & 0.090 \\
\hline $5 \mathrm{H}-1,120-122$ & 29.40 & 29.42 & CYL1413322 & 20.3 & 4.6 & 24.5 & 13.6 & 8.2 & 0.3 & 0.3 & 0.5 & & 2.7 & 1.5 & 0.6 & 0.5 & 0.0 & 0.0 & 1.7 & 0.0 & 0.3 & 8.4 & 11.9 & 0.085 \\
\hline $5 \mathrm{H}-2,26-27$ & 29.79 & 29.80 & CYL1711801 & 38.7 & 4.8 & 31.7 & 0.6 & 0.0 & 0.2 & 0.3 & 0.1 & & 1.6 & 0.6 & 0.8 & 0.0 & 0.0 & 0.0 & 2.1 & 0.0 & 0.4 & 4.7 & 13.5 & 0.099 \\
\hline $5 \mathrm{H}-3,26-27$ & 31.23 & 31.24 & CYL1712111 & 14.6 & 4.0 & 19.5 & 21.4 & 11.4 & 0.4 & 0.4 & 0.7 & & 2.3 & 0.7 & 0.1 & 0.0 & 0.0 & 0.0 & 1.5 & 0.0 & 0.2 & 9.5 & 14.3 & 0.099 \\
\hline $5 \mathrm{H}-3,41-43$ & 31.41 & 31.43 & CYL1648282 & 14.4 & 4.0 & 17.9 & 22.3 & 9.2 & 0.3 & 0.2 & 0.5 & & 2.3 & 1.7 & 0.3 & 0.2 & 0.0 & 0.9 & 0.0 & 0.0 & 0.7 & 9.8 & 15.2 & 0.096 \\
\hline $6 \mathrm{H}-1,73-75$ & 32.93 & 32.95 & CYL1413332 & 27.4 & 5.0 & 28.2 & 0.4 & 0.9 & 0.0 & 0.0 & 0.3 & & 2.7 & 0.0 & 0.0 & 0.0 & 0.0 & 0.0 & 2.9 & 0.0 & 0.0 & 12.2 & 19.9 & 0.098 \\
\hline $6 \mathrm{H}-2,25-27$ & 33.95 & 33.97 & CUBE1713081 & 24.4 & 4.2 & 27.5 & 0.4 & 0.0 & 0.0 & 0.2 & 0.3 & & 2.7 & 0.7 & 0.7 & 0.0 & 0.0 & 0.0 & & 0.0 & 0.0 & 14.5 & 24.5 & 0.111 \\
\hline
\end{tabular}

Concentrations over $3 \mathrm{wt} \%$ exceed threshold for analytical certainty of presence in sample. Only a portion of the table appears here. The complete table is available in ASCII. 